U.S. Department of Energy

Office of Civilian

Radioactive Waste Management

and

Electric Power

Research Institute
Keywords:

Spent-fuel storage

Radioactive waste processing

Radioactive waste storage

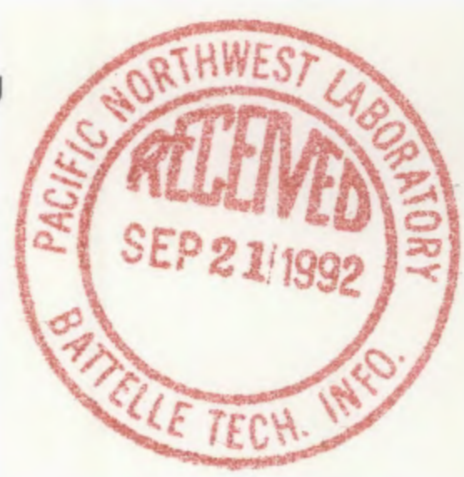

EPRI TR-101092

Project 2406-04

PNL-7334

UC-85

Interim Report

August 1992

\title{
Consolidation and Disposal of PWR Fuel Inserts
}

Prepared by

Virginia Power

Glen Allen, Virginia 



\section{$R E P O R T S U M M A R Y$}

\section{Consolidation and Disposal of PWR Fuel Inserts}

Hardware that has seen service as inserts in nuclear-fuel assemblies can add to the clutter and occupy space in the spent-fuel storage pool. A project at Surry Nuclear Power Station demonstrated techniques to process, package, and dispose of these radioactive components.

\section{INTEREST CATEGORIES}

Radioactive waste

management

Light water reactor fuel

\section{KEYWORDS}

Spent-fuel storage

Radioactive waste processing

Radioactive waste storage
BACKGROUND In 1985 and 1986, Virginia Power provided three dry-storage casks to the U.S. DOE for testing at the ldaho National Engineering Laboratory's Test Area North (TAN). Sixty-nine spent-fuel assemblies were transported by truck casks from Virginia Power's Surry Power Station to TAN for use in the three storage casks. The irradiated insert components normally stored in these 69 fuel assemblies were removed at the Surry Power Station prior to their transport. Retaining these inserts was a problem because of a shortage of space in the spent-fuel storage pool. An additional 56 insert components were added to this excess inventory when the waste component consolidation program was performed at the Surry Power Station in 1991.

OBJECTIVES To consolidate 136 irradiation insert components into containers suitable for disposal at the Chem-Nuclear low-level radioactive waste facility in South Carolina; to process these wastes in minimum time and without adversely affecting pool water quality.

APPROACH The project team used two methods to process the irradiated components. The first method used a new Chem-Nuclear light-duty crusher/shear, activated by a water hydraulic system. Longer components, consisting of burnable poison rod assemblies (BPAAs) and rod cluster control assemblies (RCCAs), were inserted vertically into the throat of the crusher/shear and segmented into 8-in lengths. Situating a CNSI 3-55 liner directly under the throat of the crusher/shear ensured that all processed parts would fall directly into the liner. The second method used a Hurst cutter to provide a final cut close to the component baseplate. Workers placed shorter components (thimble plugging devices) directly into the liner without processing.

RESULTS Using the crusher/shear and Hurst cutter provided a quick (10-day) and low-personnel-dose solution to the storage problem for 125 BPRAs, 10 thimble plugging devices, and one RCCA. During the processing, pool water quality remained good. The small amount of glass "snow"-from the crushed BPRA rodsthat was deposited in a small area of the storage pool was easily removed. Characterization of the components and classification of the disposal liner for burial as Class $\mathrm{C}$ low-level waste was quick and easy. Four to five times more hardware was packaged in the liners using the new model crusher/shear than had been packaged in previous PWR hardware projects. 
EPRI PERSPECTIVE While the final disposal of spent fuel is a major concern for utilities, other radioactive waste components also present storage problems in the limited space available in reactor spent-fuel storage pools. This project demonstrated that technology exists to process, package, and dispose of hardware such as fuel-assembly insert components. Such technology may assist in developing the more demanding equipment needed to treat the scrap hardware that results from fuel consolidation.

\section{PROJECT}

RP2406-04

Project Manager: Ray Lambert

Nuclear Power Division

Contractor: Virginia Power

For further information on EPRI research programs, call EPRI Technical Information Specialists (415) 855-2411. 


\title{
Consolidation and Disposal of PWR Fuel Inserts
}

\author{
TR-101092 \\ Research Project 2406-04 \\ PNL-7334 \\ UC-85 \\ Interim Report, August 1992 \\ Prepared by \\ VIRGINIA POWER \\ Innsbrook Technical Center \\ 5000 Dominion Boulevard \\ Glen Allen, Virginia 23060 \\ Principal Investigator \\ B. H. Wakeman
}

\section{Prepared for \\ Virginia Power}

U.S. Department of Energy

and

Electric Power Research institute 3412 Hillview Avenue

Palo Alto, California 94304

EPRI Project Manager

R. W. Lambert

High Level Waste and Spent Fuel Storage Program Nuclear Power Division 


\section{DISCLAIMER OF WARRANTIES AND LIMITATION OF LIABILITIES}

THIS REPORT WAS PREPARED BY THE ORGANIZATION(S) NAMED BELOW AS AN ACCOUNT OF WORK SPONSORED OR COSPONSORED BY THE ELECTRIC POWER RESEARCH INSTITUTE, INC. (EPRI). NEITHER EPRI, ANY MEMBER OF EPRI, ANY COSPONSOR, THE ORGANIZATION(S) NAMED BELOW, NOR ANY PERSON ACTING ON BEHALF OF ANY OF THEM:

(A) MAKES ANY WARRANTY OR REPRESENTATION WHATSOEVER, EXPRESS OR IMPLIED, (I) WITH RESPECT TO THE USE OF ANY INFORMATION, APPARATUS, METHOD, PROCESS, OR SIMILAR ITEM DISCLOSED IN THIS REPORT, INCLUDING MERCHANTABILITY AND FITNESS FOR A PARTICULAR PURPOSE, OR (II) THAT SUCH USE DOES NOT INFRINGE ON OR INTERFERE WITH PRIVATELY OWNED RIGHTS, INCLUDING ANY PARTY'S INTELLECTUAL PROPERTY, OR (III) THAT THIS REPORT IS SUITABLE TO ANY PARTICULAR USER'S CIRCUMSTANCE; OR

(B) ASSUMES RESPONSIBILITY FOR ANY DAMAGES OR OTHER LIABILITY WHATSOEVER IINCWDING ANY CONSEQUENTIAL DAMAGES, EVEN IF EPRI OR ANY EPRI REPRESENTATIVE HAS BEEN ADVISED OF THE POSSIBILITY OF SUCH DAMAGES) RESULTING FROM YOUR SELECTION OR USE OF THIS REPORT OR ANY INFORMATION, APPARATUS, METHOD, PROCESS, OR SIMILAR ITEM DISCLOSED IN THIS REPORT.

ORGANIZATION(S) THAT PREPARED THIS REPORT:

VIRGINIA POWER

Electric Power Research Institute and EPRI are registered service marks of Electric Power Research Institute, Inc.

Copyright (c) 1992 Electric Power Research Institule, Inc. All rights reserved.

\section{ORDERING INFORMATION}

Requests for copies of this report should be directed to the EPRI Distribution Center, 207 Coggins Drive, P.O. Box 23205, Pleasant Hill, CA 94523, (510) 934-4212. There is no charge for reports requested by EPRI member utilities and affiliates. 
ABSTRACT

Design and licensing of the Surry Power Station Independent Spent Fuel Storage Installation was initiated in 1982 by Virginia Power as part of a comprehensive strateay to increase spent fuel storage capacity at the Station. Designed to use large, metal dry storage casks, the Surry Installation will accommodate 84 such casks with a total storace capacitv of 811 MTU of spent pressurized water reactor fuel assemblies.

Virginia Power provided three storage casks for testing at the Idaho National Engineering Laboratory's Test. Area North and the testing results have been published by the Electric Power Research Institute. Sixty-nine spent fuel assemblies were transported in truck casks from the Surry Power Station to Test Area North for testing in the three casks. Because of restrictions imposed by the cask testing equipment. at Test Area North, the irradiated insert components stored in these fuel assemblies at Surry were removed prior to transport of the fuel assemblies.

Retaining these insert components proved to be a problem because of a shortage of spent fuel assemblies in the spent fuel storage pool that did not already contain insert components. In 1987 Virginia Power contracted with Chem-Nuclear Systems, Inc. to process and dispose of 136 irradiated insert components consisting of 125 burnable poison rod assemblies, 10 thimble plugging devices and 1 part-length rod cluster control assembly. This work was completed in August and September 1987, culminating in the disposal at the Barnwell, SC low-level radioactive waste facility of two CNS 3-55 liners containing the consolidated insert components. 


\section{ACKNOWLEDGMENTS}

The authors acknowledge the support of Virginia Power (VP); the Electric Power Research Institute (EPRI); the U.S. Department of Energy (US DOE); Chem-Nuclear Systems, Inc. (CNSI), WMG, Inc. (WMG) and especially the management and staff of the Surry Power Station.

\section{Technical Management Committee \\ M. L. Smith, Chairman (VP) \\ C. T. Snow (VP) \\ R. W. Lambert (EPRI) \\ J. M. Creer (PNL) \\ C. E. Collantes (US DOE)}

Virginia Power

T. A. Bronkmire

J. G. Fisher

D. Dziadosz

WMG

P. T. Tuite

US DOE

Dwight Shelor

C. R. Head

G. J. Bracken

J. P. Collins

J. L. Daily

D. E. Trader

\section{Surry Power Station}

J. M. Pickworth

d. S. King

A. N. Xenakis

D. K. Masingo

D. T. Reed

S. V. Ross

S. P. Sarver
CNSI

Bill Watford

William Anderson

PNL

G. H. Beeman 



\section{CONTENTS}

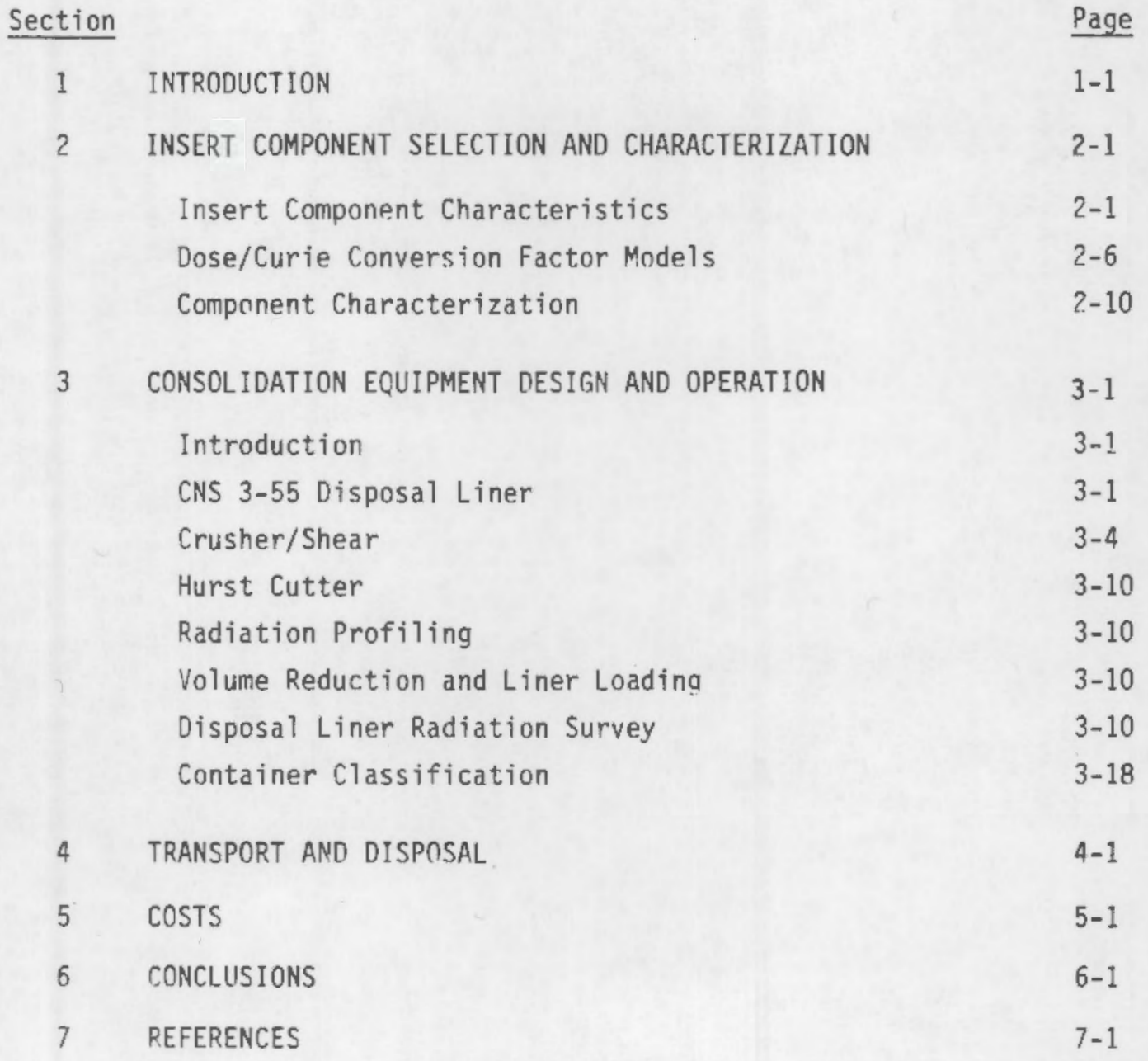





\section{ILLUSTRATIONS}

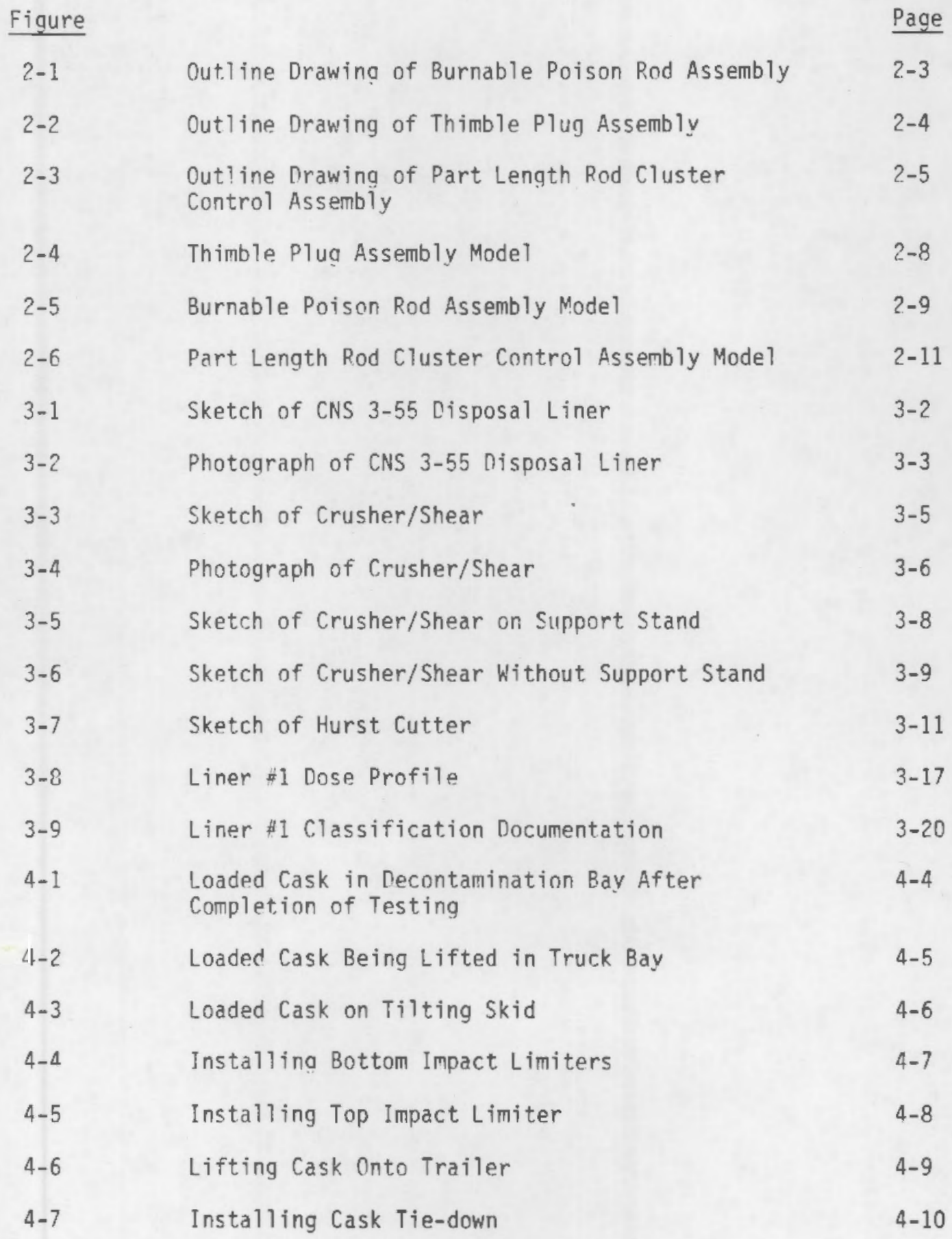





\section{TABLES}

Table

Page

2-1

PWR Hardware Constituents by Weight

2-2

$2-2$

Estimated Transuranic Content By Using Scaling

$2-7$

$2-3$ Factor Method and Cs-137 as Base

$2-4$

BPRA 8P113 Characterization Record

$?-12$

RPRA 12P184 Characterization Record

$2-13$

$2-5$

BPRA 8P03 Characterization Record

$2-14$

$2-6$

Thimble Plug 88 Characterization Record

2-15

$2-7$

Thimble Plug VIR033 Characterization Record

2-17

$2-8$

PLRCCA RS15 Characterization Record

2-18

$2-9$

PLRCCA RS13 Characterization Record

$?-19$

$3-1$

Contents of Liner \#1

$3-12$

$3-2$

Contents of Liner $\$ 2$

3-14

$3-3$

Schedule of Activities

3-16

4-1

Shipment Summary

4-3

$5-1$

Cost Breakdown

5-2 

Section 1

INTRODUCTION

When the spent fuel pool at Surry Power Station Unit Nos. 1 and 2 was designed and constructed, Virginia Power (then Vepco) assumed that reprocessing would be available. Fuel reprocessing was not and has not become available since that time. The Surry Power Station fuel pool has been reracked to the extent possible and now has a capacity of 1044 spent fuel assemblies.

With the signing of the Nuclear Waste Policy Act of 1982 (NWPA), the US DOE waS assigned the responsibility of assisting utilities with their spent fuel storage problems. The NWPA also directed the US DOE to enter into demonstration programs of spent fuel storage systems at utility reactor sites.

In August of 1983, in response to the US DOE's Solicitation for Cooperative Agreement Proposal (SCAP), Virginia Power proposed a program involving cask performance testing at a federal site in support of a licensed demonstration of an Independent Spent. Fuel Storage Installation (ISFSI) at the Surry Power Station. A Cooperative Agreement was signed by Virginia Power and the US DOE in March 1984. Virginia Power also signed a separate agreement with EPRI as part of the program. Cask testing in support of the Surry ISFSI was conducted at the Idaho National Engineering Laboratory's Test Area North (TAN) by the US DOE, EG\&G Idaho, and the Pacific Northwest Laboratory. Results of these cask tests are published in References $1,2,3$ and 4 .

Virginia Power's part of the Cooperative Agreement involved the selection and purchase of casks to be tested at a federal site, selection and shipping of spent fuel assemblies to the federal site and the design, licensing and demonstration of a dry cask ISFSI at the Surry Power Station (Reference 5).

In 1985 and 1086 , sixty-nine spent fuel assemblies were transported by truck cask from Surry to TAN for testing in the CASTOR $V / 21$, Westinghouse $M C-10$ and Transnuclear TN-24P. As part of the cask testing, thermocouple lances were 
inserted through the cask lid into the guide tubes of certain fuel assemblies. This meant that the irradiated insert component stored in the test fuel assemblies had to be removed prior to transport of the fuel assemblies to TAN.

Retaining these insert components proved to be a problem because of a shortage of spent fuel assemblies in the spent fuel storage pool that did not already contain irradiated insert components. With the increasing use of burnable poison rod assemblies (RPRAs) for reactivity control and power shaping, and the future replacement of the rod cluster control assemblies (RCCAs) in both Surry units, this situation would have led to the storage of insert components in the very limited amount of empty spent fuel storage rack locations.

To resolve this problem before replacement of the RCCAs, Virginia Power contracted with Chem-Nuclear Systems, Inc. (CNSI) in early 1987 to process irradiated insert components from the Surry pool, package this hardware and ship it to CNSI's Barnwel1, SC burial site for disposal. WMG provided support as subcontractor to CNSI in characterization and classification of the hardware and preparation of the shipment/disposal documents. 
Section 2

INSERT COMPONENT SELECTION AND CHARACTERIZATION

\section{INSERT RCMPONENT CHARACTERISTICS}

This section describes the Surry irradiated insert components and the parameters used to characterize this hardware for shipment and disposal as low-level radioactive waste under 10CFR61.

The parameters needed for component characterization include:

- The types of hardware to be shipped

- The physical characteristics of components such as volume, weight, and chemical constituent content

- The irradiation history of components and aroups of components

- The dose/curie conversion factors

- The radiation profiles for individual components

The information used to define the physical and chemical constituent characteristics of all components included:

- Westinghouse component drawings

Westinghouse drawing 617F428, Surry BPRA's

Westinghouse drawing 5649D12, Thimble Plug

Westinghouse drawing 883D310, RCCA outline

- WMG data on irradiated hardware constituents

- ASTM specifications for Type 304 stainless steel

- Westinghouse/Sequoyah data on Inconel-750x ${ }^{T M}$ composition and spring weights

Five different types of components were characterized, including part-length RCCA's (PIRCCAS), BPRA's with 8,12 and 20 burnable poison rnds, and thimhle plug assemblies. The principle physical characteristics of these components are presented in Table 2-1. Drawings of these components are provided in Figures 2-1, 2-2 and 2-3. All components are 
Table 2-1

PWR HARDWARE CONSTITUENTS BY WEIGHT

(Kilograms)

\begin{tabular}{|c|c|c|c|c|c|}
\hline Material & $\begin{array}{l}\text { Thimble } \\
\text { Plug }\end{array}$ & PLRCCA & 8 Finger & $\begin{array}{c}\text { BPRA } \\
\text { 12 Finger }\end{array}$ & 20 Finger \\
\hline 304 SST & 5.020 & 16.281 & 11.546 & 14.721 & 21.070 \\
\hline Inconel $^{T M}$ & 0.422 & 0.726 & 0.245 & 0.245 & 0.245 \\
\hline $\begin{array}{l}\text { Borosilicate } \\
\text { Glass }\end{array}$ & $N / A$ & $N / A$ & 2.993 & 4.490 & 7.483 \\
\hline Silver & $N / A$ & 46.259 & $\mathrm{~N} / \mathrm{A}$ & $N / A$ & $N / A$ \\
\hline Indium & $\mathrm{N} / \mathrm{A}$ & 8.662 & $N / A$ & N/A & N/A \\
\hline Cadmium & $N / A$ & 2.902 & $N / A$ & $\mathrm{~N} / \mathrm{A}$ & $N / A$ \\
\hline TOTAL & 5.442 & 74.830 & 14.784 & 19.456 & 28.798 \\
\hline TOTAL (Lbs.) & 12.000 & 165.000 & 32.600 & 42.900 & 63.500 \\
\hline $\begin{array}{l}\text { Wasţe Volume } \\
\left(\mathrm{cm}^{3}\right)\end{array}$ & 680 & 48,989 & 3,511 & 4,927 & 7,759 \\
\hline $\begin{array}{l}\text { Waste Volume } \\
\left(\mathrm{ft}^{3}\right)\end{array}$ & 0.024 & 1.730 & 0.124 & 0.174 & 0.274 \\
\hline
\end{tabular}




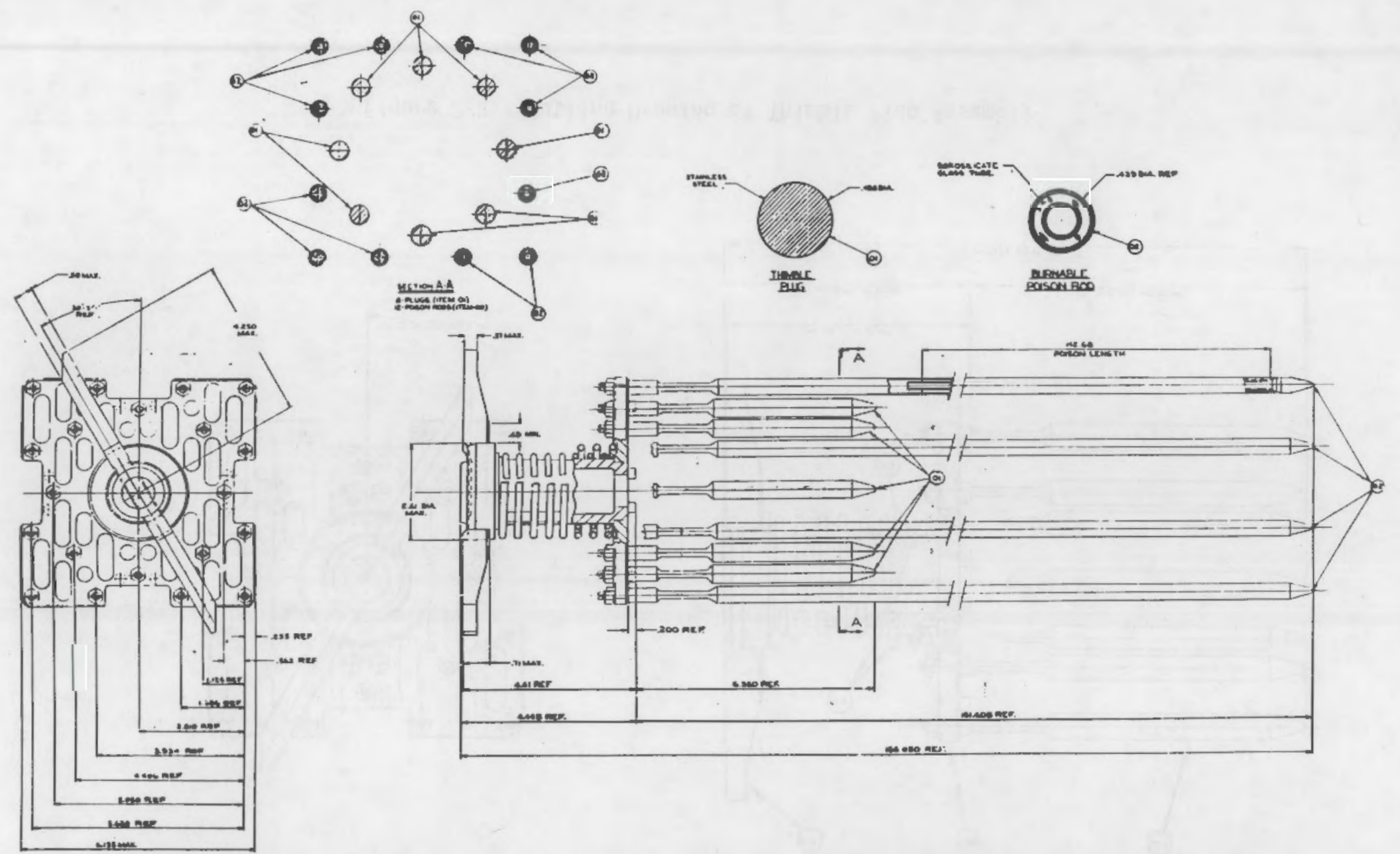

Figure 2-1. Outline Drawing of Burnable Poison Rod Assembly 

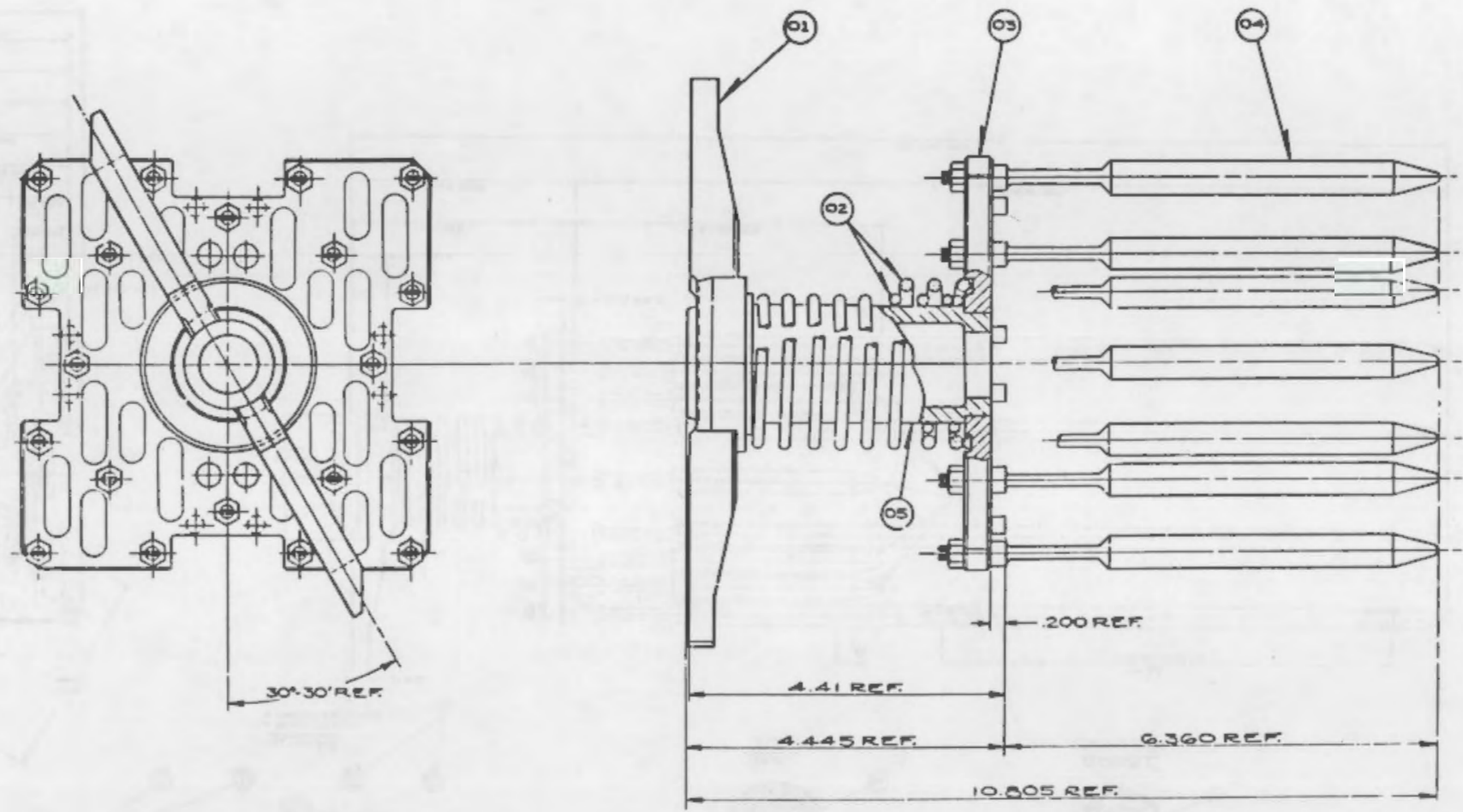

Figure 2-2. Outline Drawing of Thimble Plug Assembly 

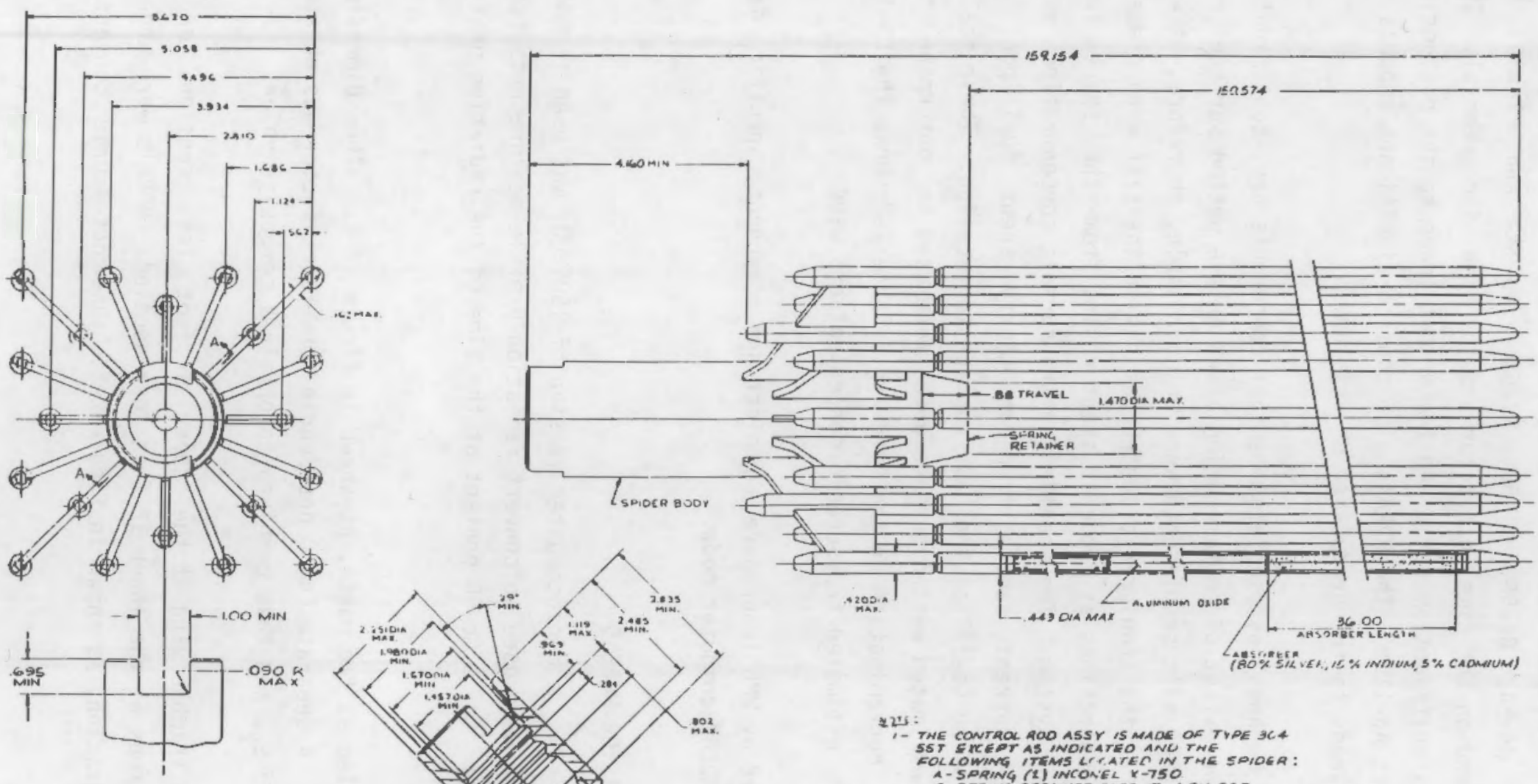
1- THE CONTROC 200 ASSY IS MAOE OF TVRE BC4
FOL LOWIMV ITIMS LTATES IN THE SOIOGA
- SARTAG RETAMTER YYSE

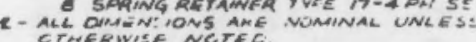

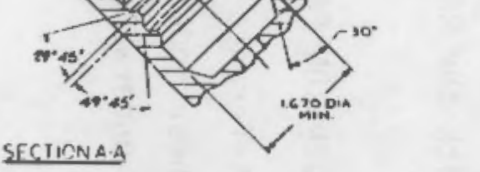

SECIIONA.A

Figure 2-3. Outline Drawing of Part Length Rod Cluster Control Assembly 
primarily constructed of Type 304 SST and contain Inconel-750X TM springs on the upper assembly. These constituents lead to production of the activation product nuclides $\mathrm{Co}-60, \mathrm{Fe}-55, \mathrm{Mn}-54, \mathrm{Co}-58, \mathrm{Ni}-59, \mathrm{Ni}-63, \mathrm{Nb}-94$ and $\mathrm{Tc}-99$ in concentrations that depend on the time in reactor and the time since removal. The PLRCCA's also contain a significant amount of Ag-In-Cd that leads to the production of the activation product Ag- $110 \mathrm{~m}$. The BPRA's also contain significant amounts of borosilicate glass that leads to the production of tritium.

The RADCOR (Reference 6) methodology used assumes that components are contaminated by transuranics, with the extent of contamination based on the wetted surface area of the component. Fuel pool silt sample data were not available, therefore, it was conservatively assumed that the transuranic concentrations in the silt were present in the same relative concentrations as those in spent resins from the spent fuel storage pool filtration system. The spent resin transuranic concentrations were used in conjunction with a current sample from the Surry spent fuel pool to estimate transuranics using Cs-137 as the base nuclide for scaling. These scaled concentrations plus the estimated wetted surface areas were used to determine the extent of transuranic contamination on the hardware. Table 2-2 shnws the CS-137 based scaling factors and estimated transuranic concentrations used.

This information was used by WMG to prepare a project and component specific data base for use with the RADCOR computer code.

\section{DOSE/CURIE CONVERSION FACTOR MODELS}

MICROSHIELD (Reference 7), a microcomputer version of ISOSHLD, was used to model components. These models were used to convert radiation profile measurements taken at 6 inches underwater to a c0-60 content at the time of the radiation profile measurement.

Thimble plugs were modeled as two parts, as shown in Finure 2-4. The dimensinns shown are in inches. A separate Co-60 dose/curie conversion factor was obtained for each section, $S_{1}$ and $S_{2}$, and then compined to ohtain a composite value.

BPRA's are similar to a thimble plug at the upper 1 foot long section, and a rectangular array of rods at the lower 12 foot long section. BPRA's were modeled to reflect this configuration, as shown in Figure 2-5. One dose/curie conversion 
Table 2-2

ESTIMATED TRANSURANIC CONTENT BY USING

SCALING FACTOR METHOD AND Cs-137 AS BASE

$\mathrm{Cs}-137=2.778 \mathrm{E}-5 \mathrm{uci} / \mathrm{cc}$

Nuclide

$\mathrm{Pu}-238$

Pu-239/240

Pu-241

Am- 241

$\mathrm{Cm}-242$

$\mathrm{Cm}-243 / 244$
Scaling

Factor

$2.91 E-4$

9.09E-5

1.47E-2

1. $53 \mathrm{E}-4$

$1.13 \mathrm{E}-4$

$1.09 \mathrm{E}-4$
Estimated Transuranic Content

$\mathrm{SF}$ (nuclide) $\times \mathrm{CS}-137$

$8.08 \mathrm{E}-9$

2. $53 \mathrm{E}-9$

4.09E-7

4. $24 E-9$

3.13E-9

3. $03 \mathrm{E}-9$ 


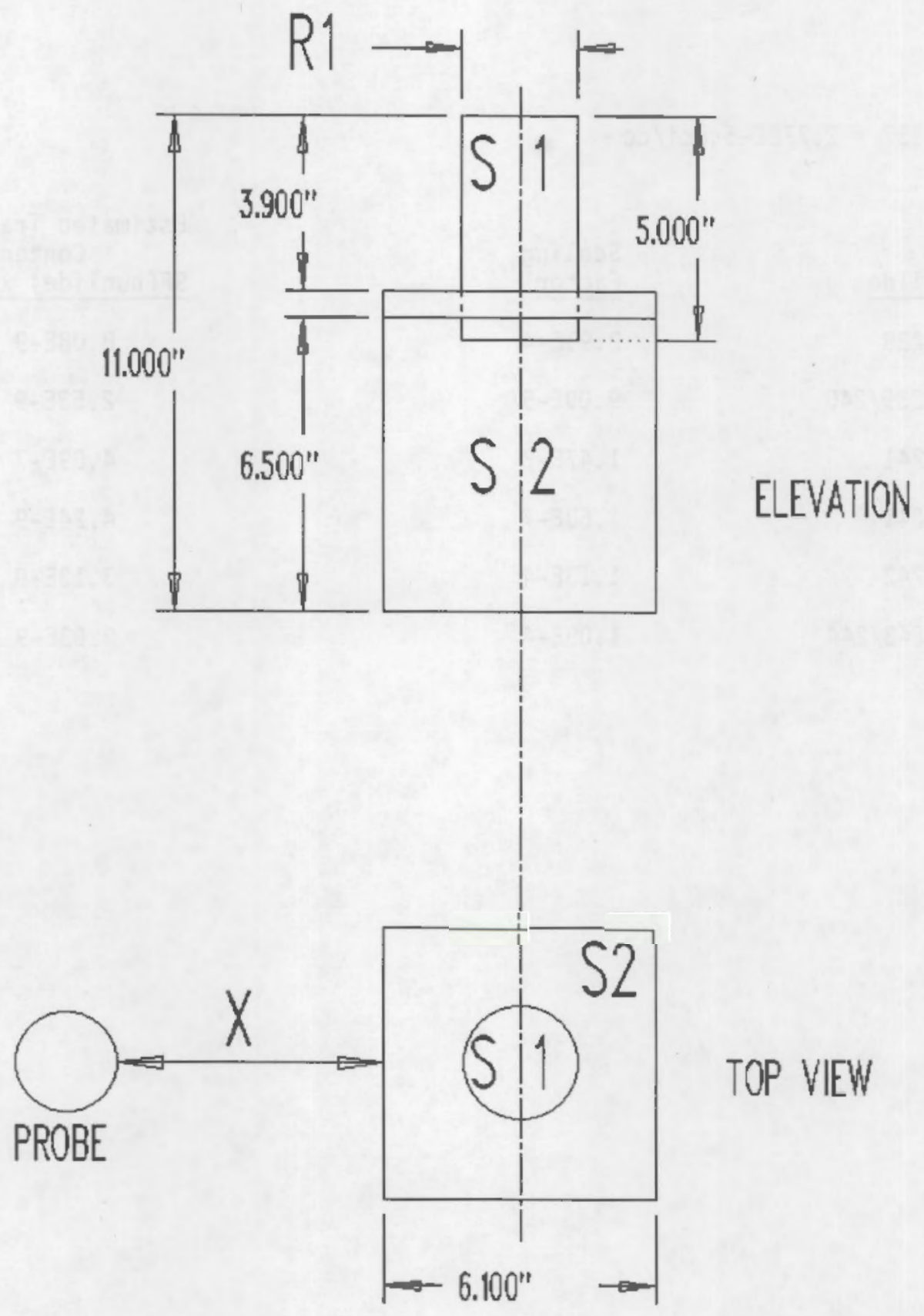

Figure 2-4. Thimble Plug Assembly Model 

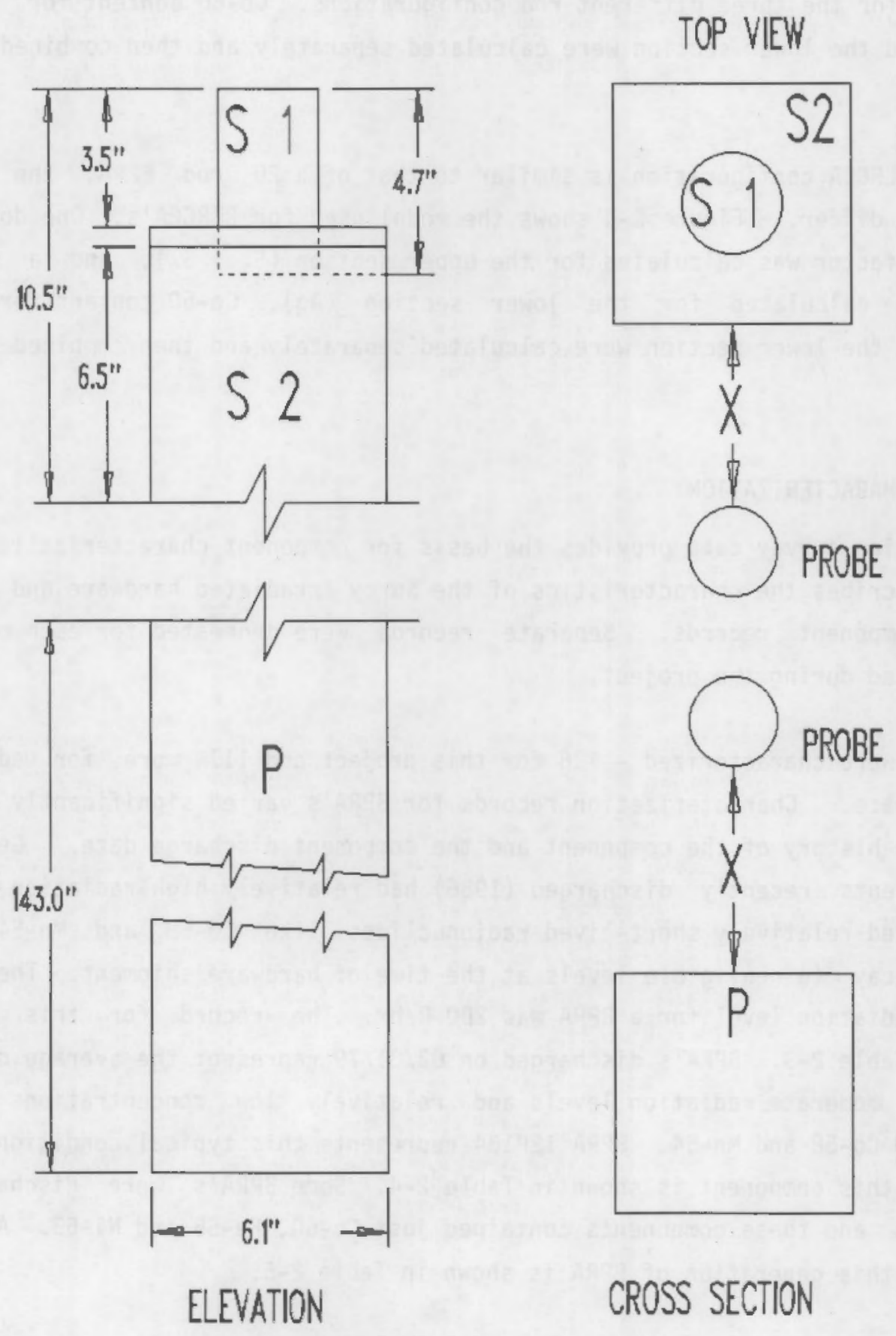

Figure 2-5. Burnable Poison Rod Assembly Model 
factor was calculated for the upper, thimble plug-like sertion $\left(S_{1}+S_{2}\right)$, and a second set of conversion factors was calculated for the longer rectangular section. Three separate dose/curie conversion factors were calculated for the lower sections to account for the three different rod configurations. Co-60 content for the top section and the lower section were calculated separately and then combined for the assembly.

While the PLRCCA configuration is similar to that of a 20 rod BPRA, the overall dimensions differ. Figure :-6 shows the model used for PLRCCA's. One dose/curie conversion factor was calculated for the upper section $\left(S_{1}+S_{2}\right)$, and a separate factor was calculated for the lower section (Ag). Co-60 content for the top section and the lower section were calculated separately and then combined for the assembly.

\section{COMPONENT CHARACTERIZATION}

The radiation survey data provides the basis for component characterization. This section describes the characteristics of the Surry irradiated hardware and presents typical component records. Separate records were generated for each component characterized during the project.

243 BPRA's were characterized - 126 for this project and 117 more for additional storage space. Characterization records for BPRA's varied sianificantly with the irradiation history of the component and the component discharge date. Generally, the components recently discharged (1986) had relatively high radiation profiles and contained relatively short-lived radionuclides like $\mathrm{Co}-58$ and $\mathrm{Mn}-54$, which usually decay to negligible levels at the time of hardware shipment. The highest measured radiation level for a BPRA was $200 \mathrm{R} / \mathrm{hr}$. The record for this BPRA is shown in Table 2-3. BPRA's discharged on $02 / 01 / 79$ represent the average condition seen, i.e., moderate radiation levels and relatively low concentrations of the short-lived Co-58 and Mn-54. BPRA 12P184 represents this typical condition and the record for this component is shown in Table 2-4. Some BPRA's were discharged in the 1970's and these components contained just Co-60, Fe-55 and Ni-63. A typical record for this generation of BPRA is shown in Table 2-5.

Nineteen thimble plug assemblies were characterized for the project. The characteristics of these components varied from that shown in Table 2-6 for the one 

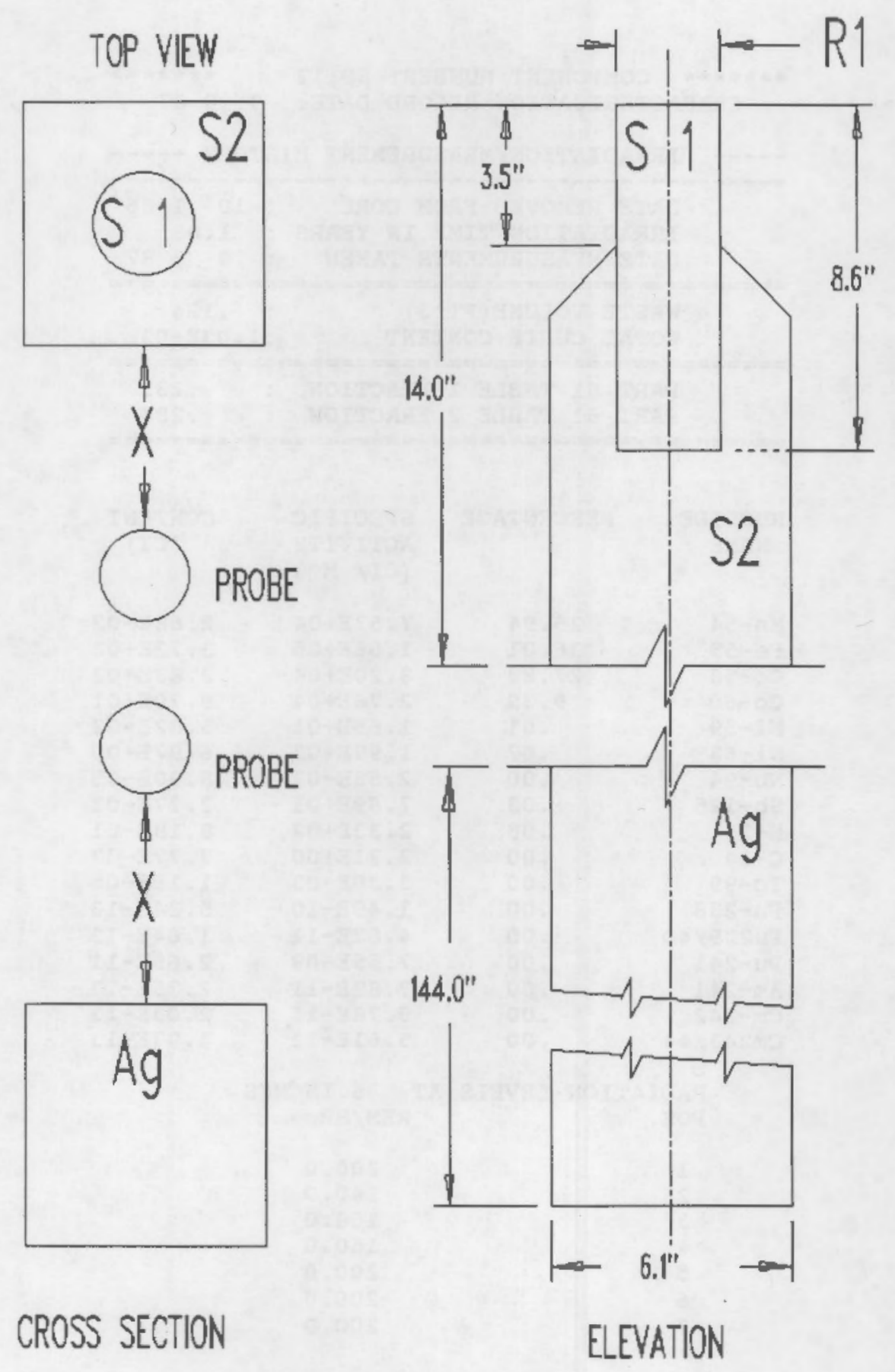

Figure 2-6. Part Length Rod Cluster Control Assembly Model 
Table 2-3

BPRA 8P113 CHARACTERIZATION RECORD

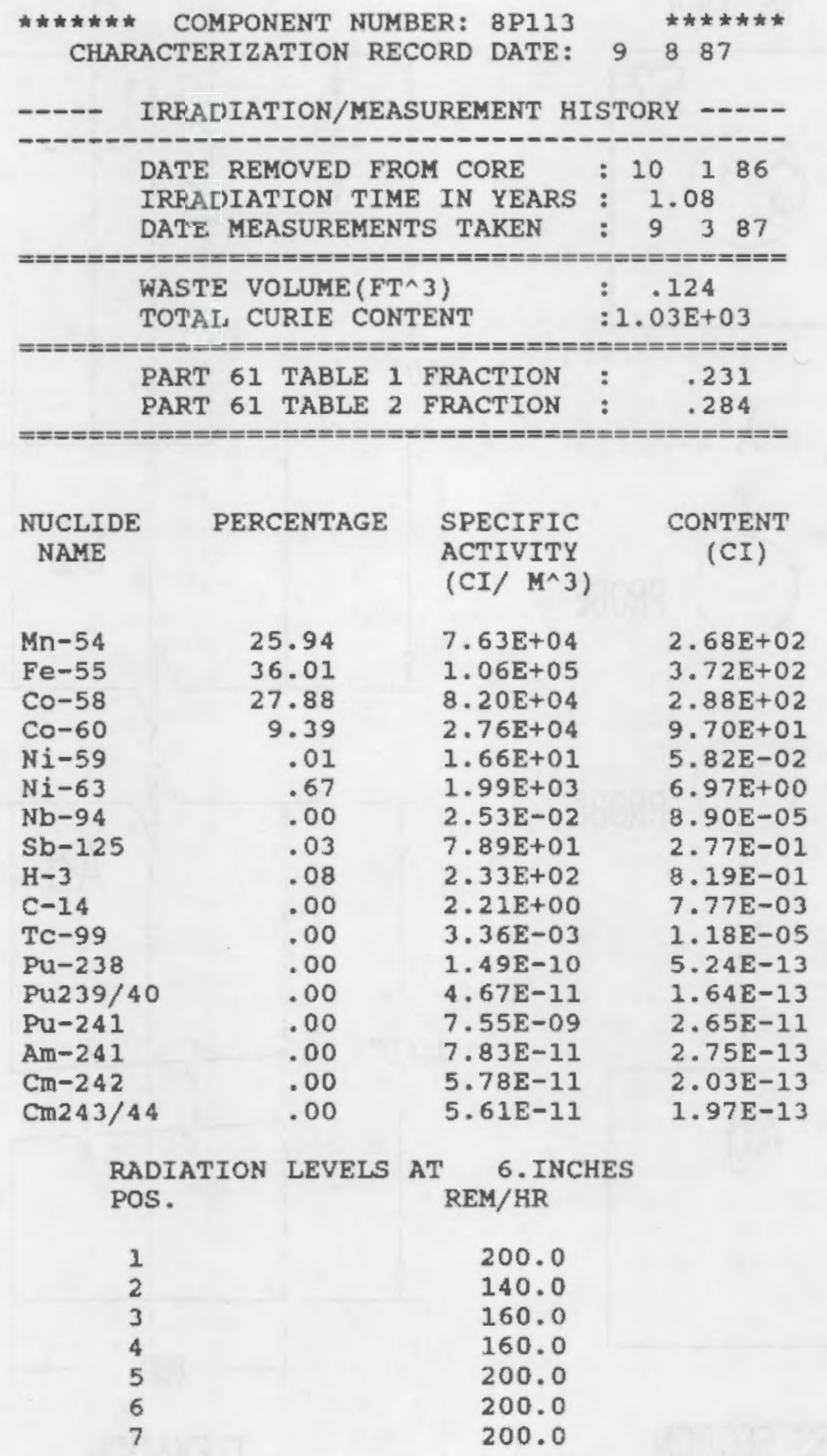


Table 2-4

BPRA 12P184 CHARACTERIZATION RECORD

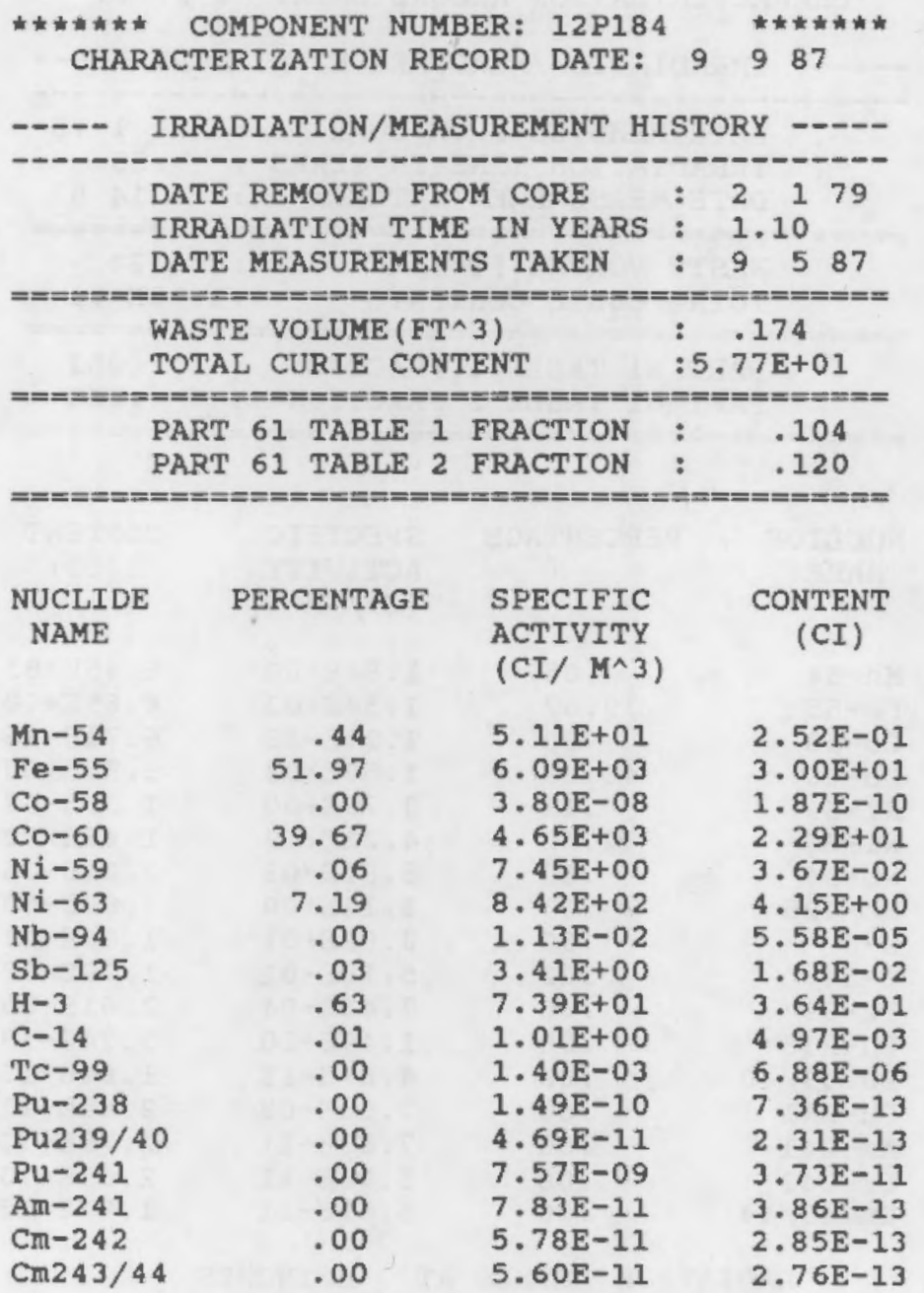

RADIATION LEVELS AT 6.INCHES POS. REM/HR

30.0

30.0

40.0

50.0

50.0

50.0 
Table 2-5

BPRA 8P03 CHARACTERIZATION RECORD

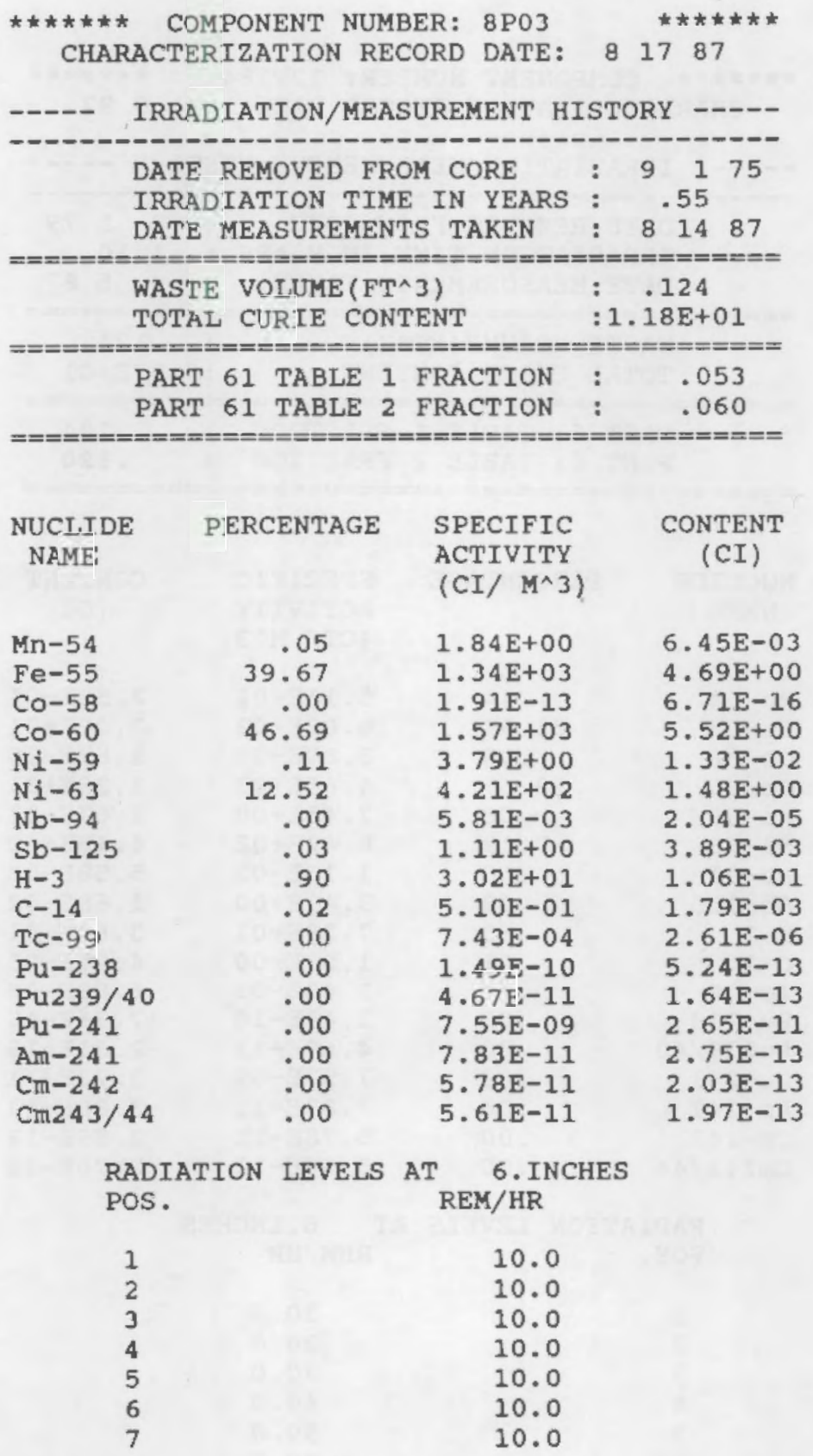


Table 2-6

THIMBLE PLUG 88 CHARACTERIZATION RECORD

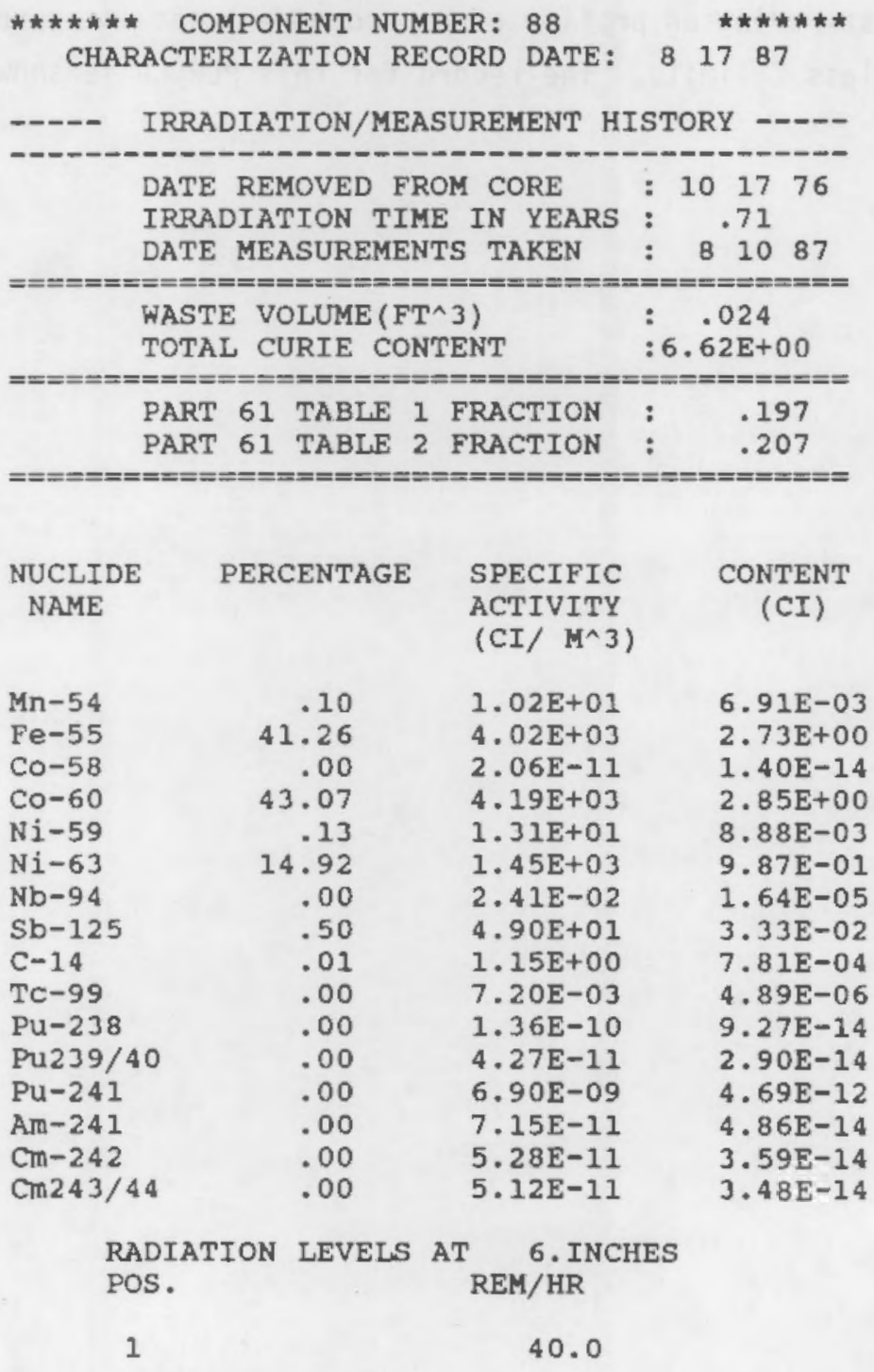


cycle irradiated assembly 88 to that shown in Table 2-7 for VIR033, an assembly irradiated for two cycies.

Three PLRCCA's were characterized for the proiect. Two PLRCCAs hàd relatively low radiation profiles and a typical record is shown in Table 2-8. One PLRCCA, RS-13, showed the highest radiation profile of any component and it approached 90 percent of the 10CFR61 Class C limits. The record for this PLRCCA is shown in Table 2-9. 
Table 2-7

THIMBLE PLUG VIR033 CHARACTERIZATION RECORD

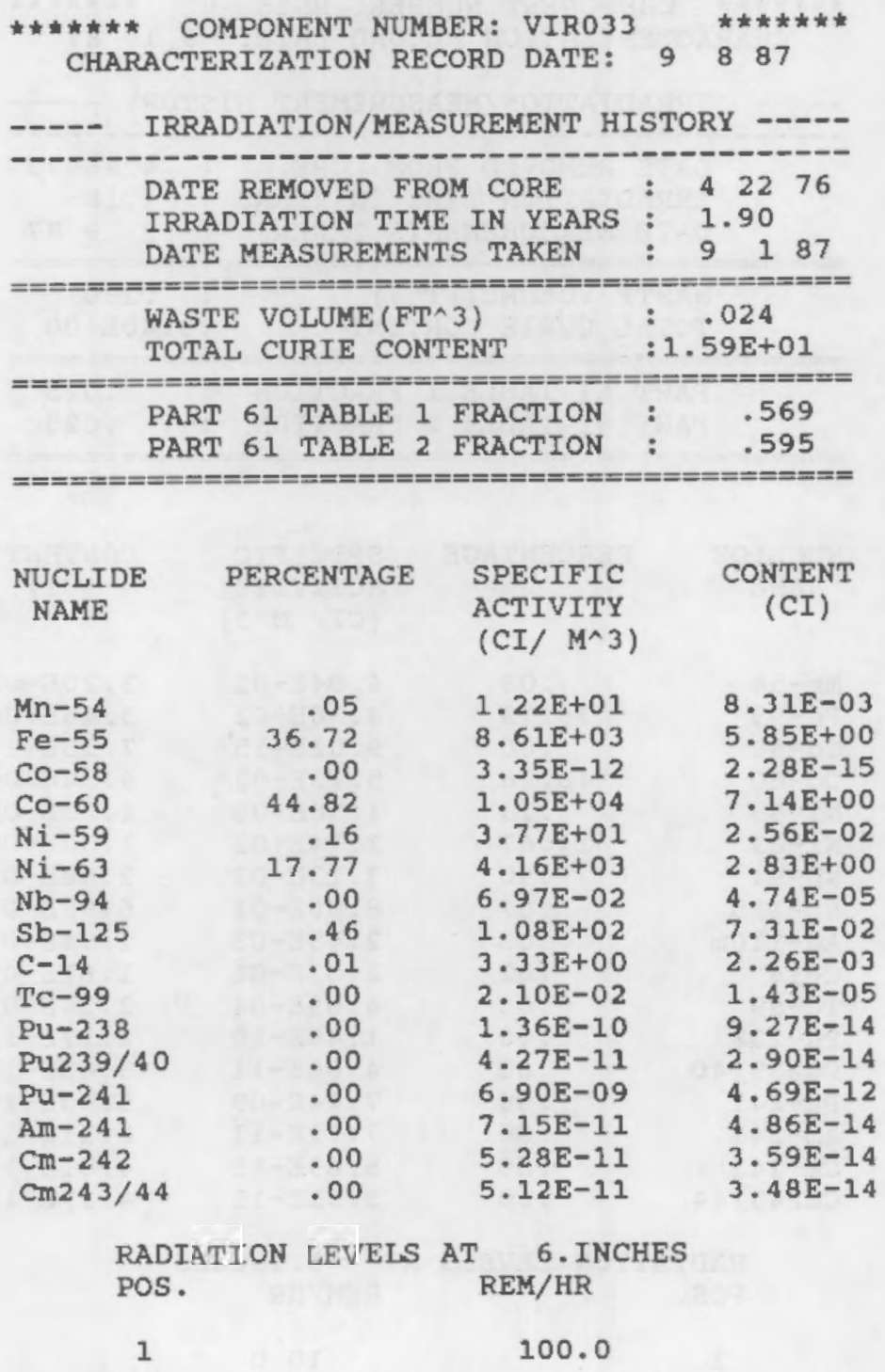


Table 2-8

PLRCCA RS15 CHARACTERIZATION RECORD

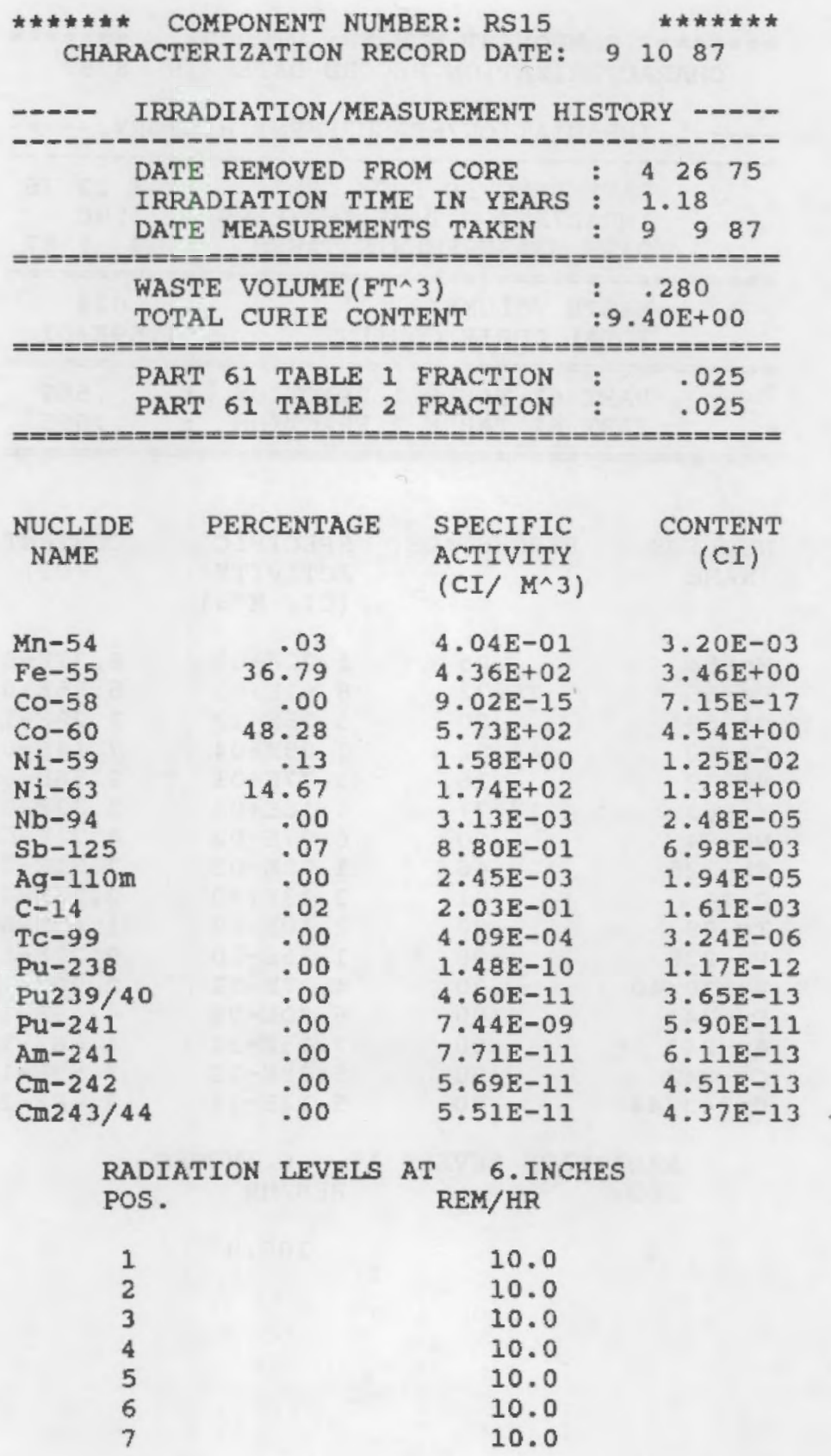


Table 2-9

PLRCCA RS13 CHARACTERIZATION RECORD

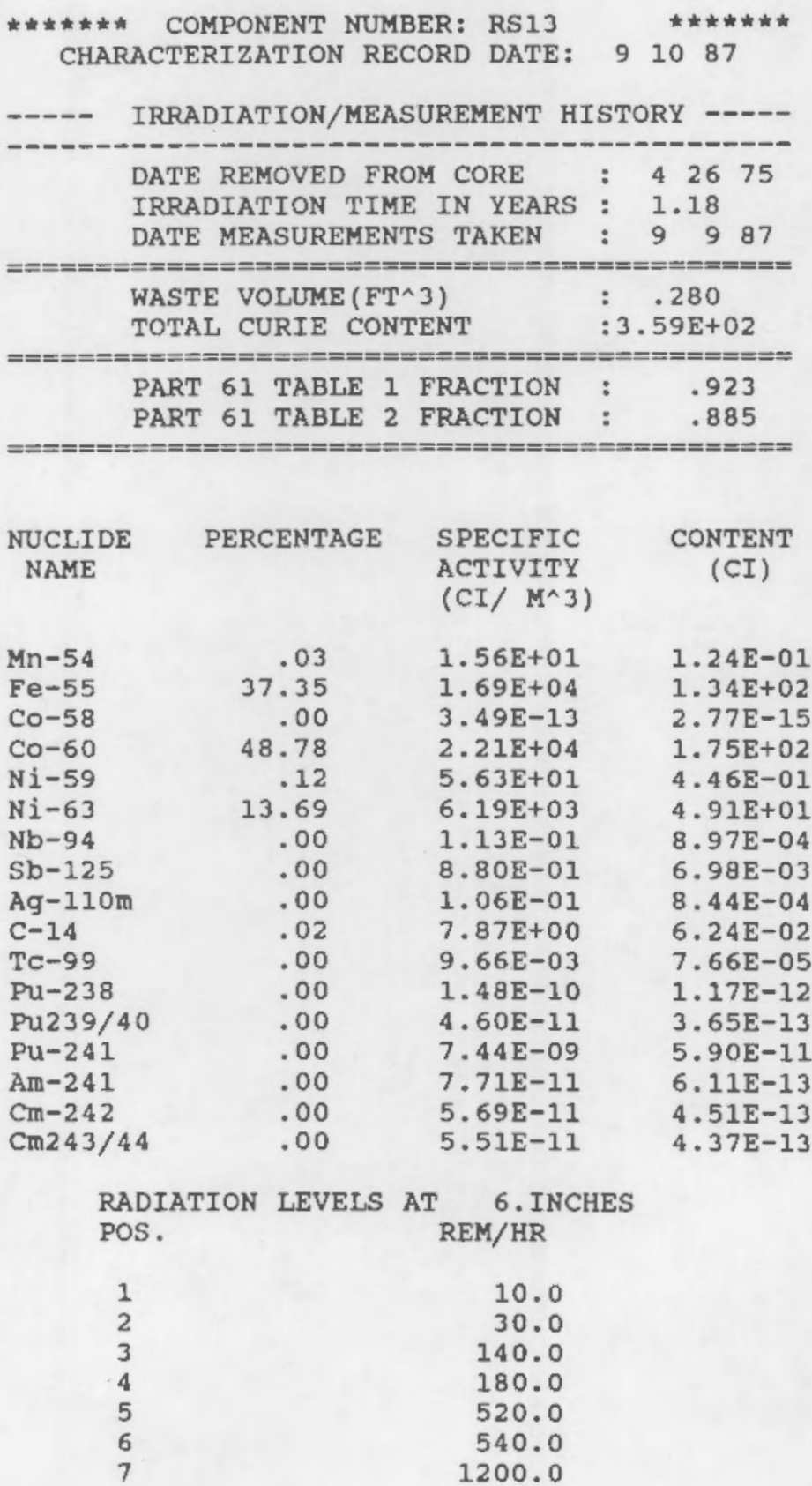





\section{Section 3}

\section{CONSOLIDATION EQUIPMENT DESIGN AND OPERATION}

\section{INTRODUCTION}

The irradiated insert components were processed by employing two methods to provide consolidation for more efficient packaging. The first method incorporates the use of the CNSI light duty crusher/shear, which is actuated by a water hydraulic system. For the BPRAs, they were inserted vertically into the throat of the crusher/shear and were segmented into $20 \mathrm{~cm}$ ( $8 \mathrm{in.})$ lengths that achieved the most efficient packaging. A CNSI 3-55 liner was situated directly under the throat of the crusher/shear in order to ensure that no additional handling of the BPRA was required and that all processed pieces would fall directly into the liner. The crusher/shear can develop a 63 tonne shear/crush force, which is more than necessary for seomenting the BPRAs.

The second method utilized a Hurst cutter for the final cut close to the BPRA baseplate and was necessary because the crusher/shear could not be used so close to the baseplate. The Hurst cutter was operated underwater and processing was performed directly over the liner to ensure decreased handlina time and to reduce the possibility of processed fragments falling to the bottom of the pool. The baseplates was then placed directly into the liner.

The thimble plugging devices were packaged, without processing, directly into the liner using long-handled, pneumatic tools. The PLRCCA was processed in the same manner as the BPRAs.

\section{CNS 3-55 DISPOSAL LINER}

The CNS 3-55 disposal liners are $2.75 \mathrm{~cm}$ (108 in) by $87 \mathrm{~cm}$ (34 in) right cylinders. The opening of the liner is fitted with a bolted lid. The liners are constructed of carbon steel and have two coats of a pool compatible, white epoxy coating. The effective disposal volume is approximately $1.7 \mathrm{~m}^{3}\left(60 \mathrm{ft}^{3}\right)$. The empty weight of the CNS 3-55 liner is $430 \mathrm{kgs}$ (945 ibs) with a gross maximum weight of $4180 \mathrm{kgs}$ $(9,220$ lbs). A drawing and photograph of the CNS 3-55 liner are included as Figures 3-1 and 3-2. 


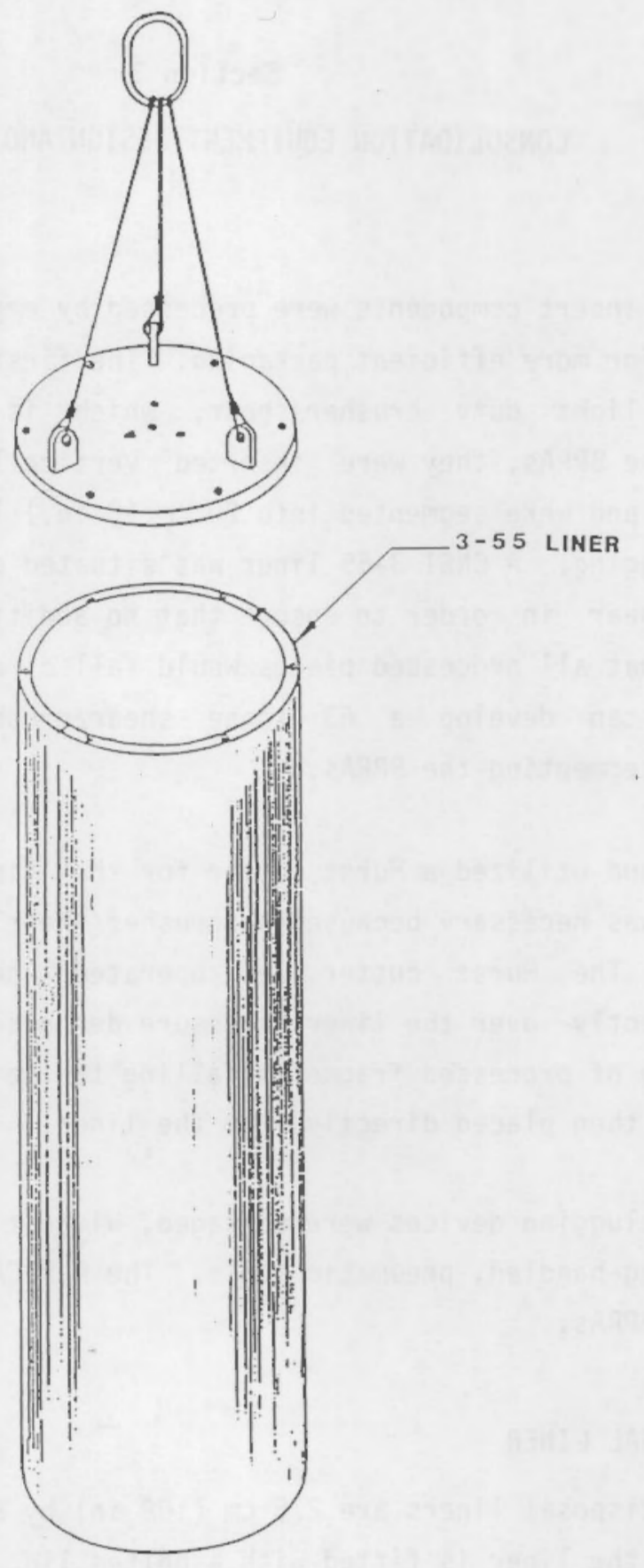

Figure 3-1. Sketch of CNS 3-55 Disposal Liner 


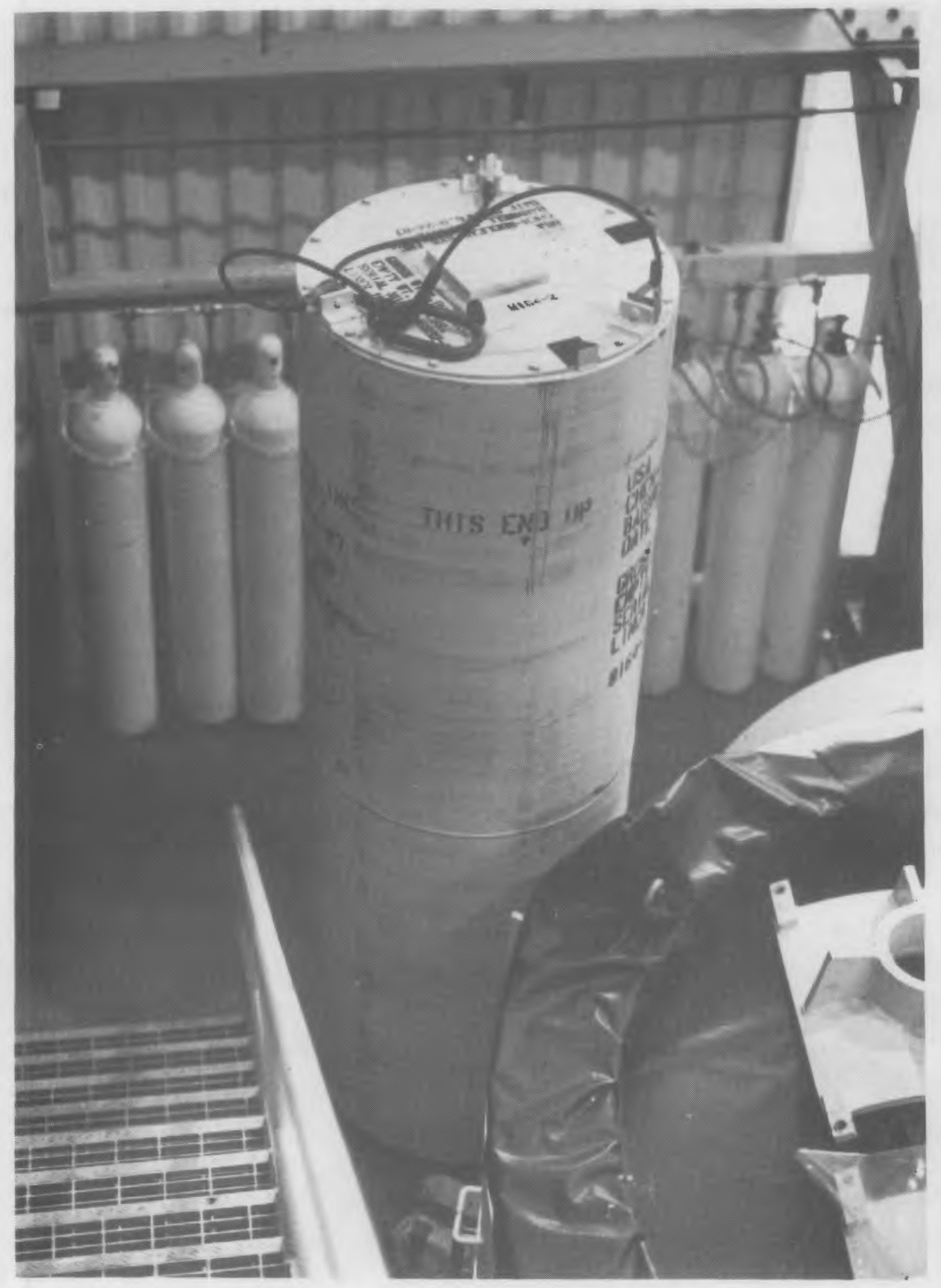

Figure 3-2. Photograph of CNS 3-55 Disposal Liner 
The liners are designed and fabricated under Chem-Nuclear's Quality Assurance Program and are approved for disposal of irradiated hardware at the Barnwel1 Low-Level Radioactive Waste Management Facility.

\section{CRUSHER/SHEAR}

The CNSI liaht duty crusher/shear is a remotely operated device for crushing and shearing irradiated hardware from nuclear facilities. The device provides a high degree of waste volume reduction that results in an increase in waste container efficiency. The unit is operated using water as the hydraulic fluid, which ensures that the pool water is not contaminated with hydraulic fluid in the event of hydraulic system leaks. The irradiated hardware, after first heing crushed and then sheared to the desired length, falls directly into a waste container. A drawing and a photograph of the crusher/shear in the Surry spent fuel storage pool are included as Figures $3-3$ and 3-4.

Process rates vary depending upon the specific piece of hardware and on the availability of plant support. The crusher/shear can process pieces with square or round cross-sections of up to $16 \mathrm{~cm}(6.25 \mathrm{in})$ and $20 \mathrm{~cm}(7.90 \mathrm{in})$, respectivelv.

The crusher/shear frame is made of type 304 stainless steel bar and plate. The frame's material has been welded and machined to form a smooth and rigid unit, capable of withstanding the extremely high forces generated during operation. The frame provides mounting surfaces for the driver cylinders and the tracks which guide the crusher anvils and the shear knives.

The crusher is a roller-guided weldment driven by a hydraulic cylinder and, like the frame, is made from 304 stainless steel. It has massive surfaces, moving and fixed, for crushing materials having ultimate strengths of up to $7000 \mathrm{~kg} / \mathrm{cm}^{2}$ $(100,000 \mathrm{psig})$ and hardness of up to Rnckwell C40. The crusher also serves as a clamp to hold the hardware during the shearing process.

The shear is composed of a "fixed knife" or anvil and a moving knife. The fixed knife is mounted on the leadina face of the crusher block and moves with the black. However, during the shearing process, the crusher block is stationary and the knife is "fixed." The moving knife is mounted on and recessed into the blade holder which travels in the blade guides. The blade guides are attached to the bottom of the shear frame. 


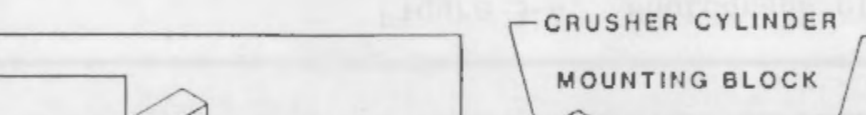

GUIDE ROLLERS

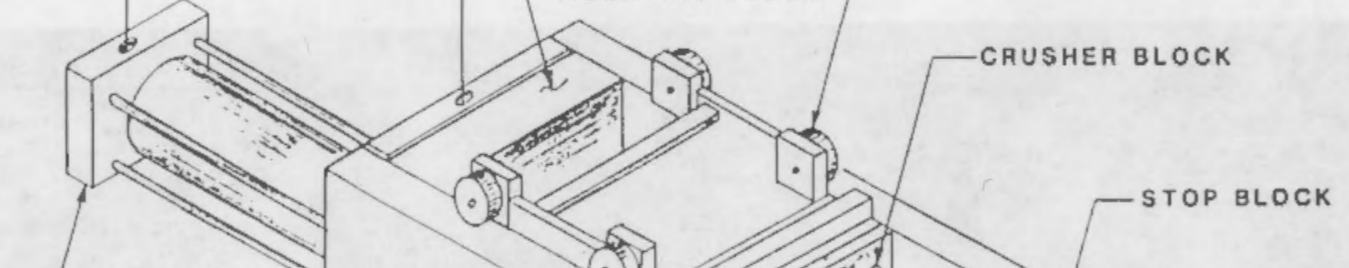

SHEAR CYLINDER

HYDRAULIC PUMP

CRUSHER CYLINDER

HYDAAULIC PUMP

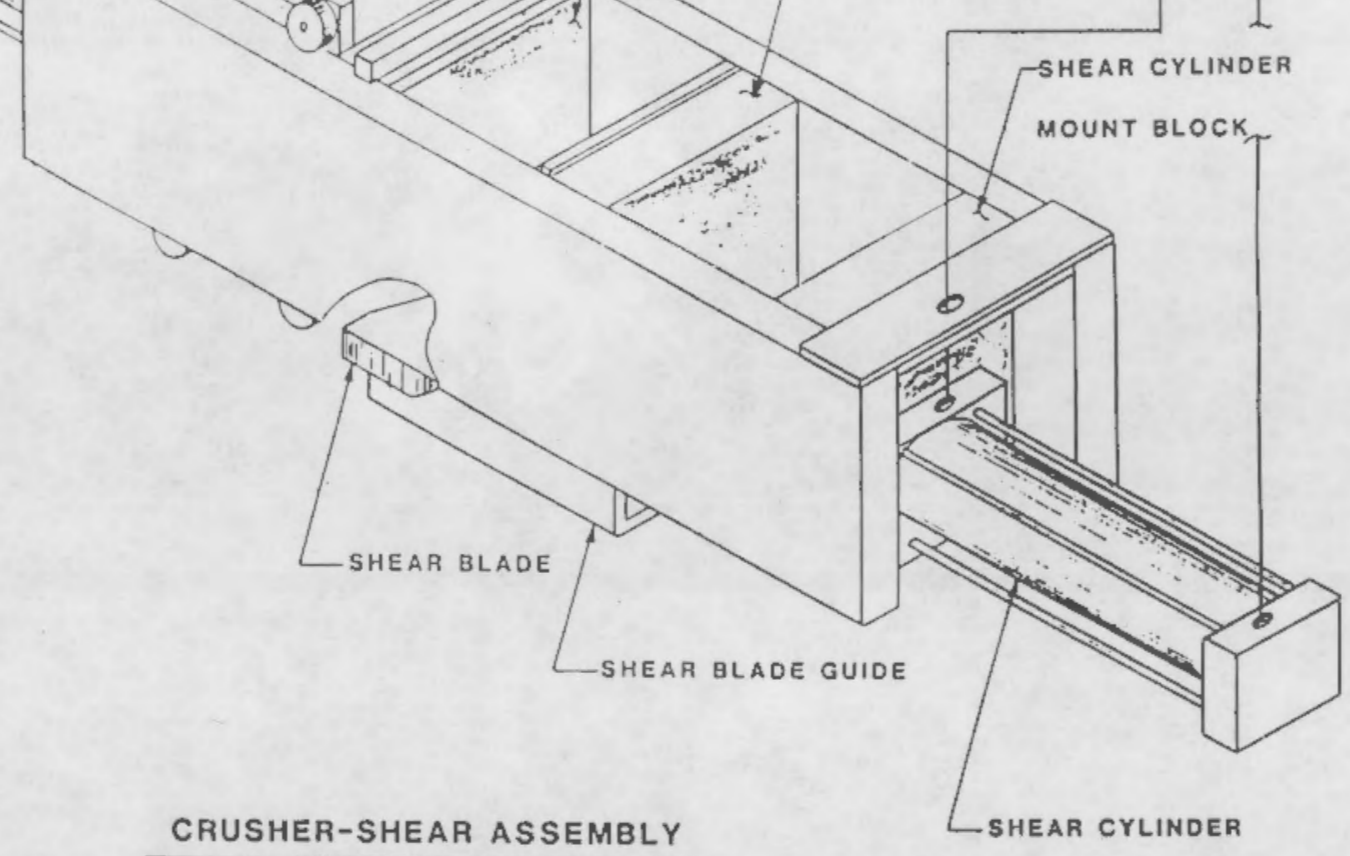

OVERALL OIMENSIONS $2 \times 2 \times 7$

Figure 3-3. Sketch of Crusher/Shear 


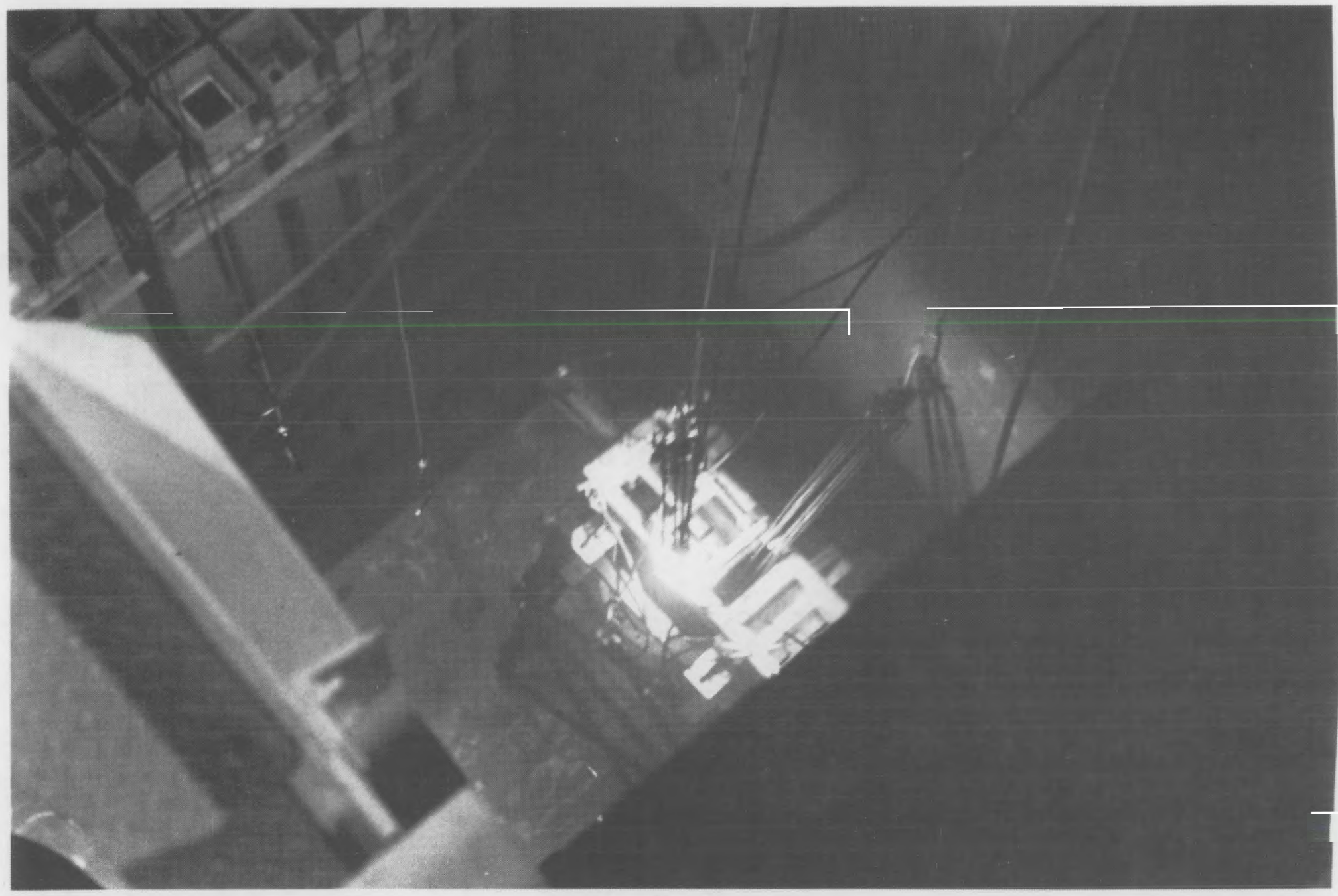

Figure 3-4. Photograph of Crusher/Shear 
The clearance between the blades is adjustable and is specified after an engineering review of the particular hardware to be sheared. The crusher/shear was designed and fabricated to reauire minimal on-site maintenance, blade change, equipment assembly/disassembly and decontamination.

The hydraulic cylinders are non-lubricated and are designed for submerged operation with water acting as a hydraulic fluid. The compact hydraulic pumps were selected to minimize the working space reouired. The pumps, which provide positive displacement, are of a dependable diaphragm and piston type.

The shear support stand is constructed from tubular steel and is painted with an epoxy paint. Bolted to the shear frame, the stand supports the shear directly above the waste container. This orientation permits the shear and the stand to be set in the pool as a unit, thereby optimizing pool floor space. A drawing of the support. stand is shown in Figure 3-5.

The shear may also be positioned directly on top of the waste container. In this position, the process liner also serves as the support fixture. Utilizing this method, the process pieces and any shear fines will fall directly into the liner below. This technique is illustrated in Figure 3-6.

The compact design of the crusher/shear permits operation in extremely confined pool areas and also reduces setup time. The shear and hydraulic units are shipped in a single LSA box, and the support stand, if required, is shipped in a second box. Setting up the crusher/shear after removal from the boxes requires approximately four (4) hours, and includes the following steps.

- Connect air and hydraulic hoses

- Fill hydraulic reservoirs with water

- Cycle the crusher/shear to purge air from the system

- Bolt the crusher/shear to the sunpart stand, if required

- Position the waste container in the pool

- Position the shear on or above the waste container 


\section{CRUSHER SHEAR AND STAND}

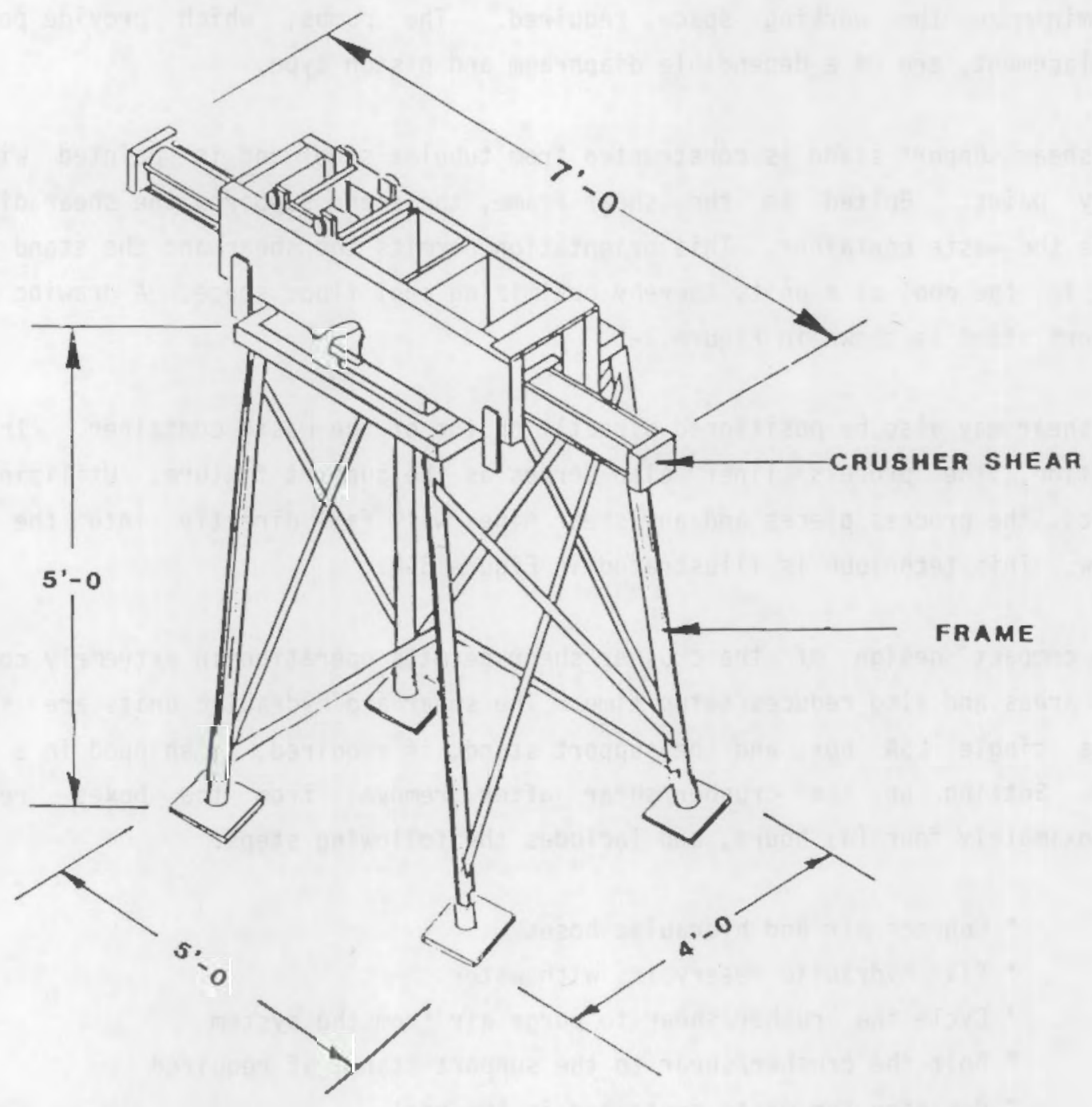

Figure 3-5. Sketch of Crusher/Shear on Support Stand 


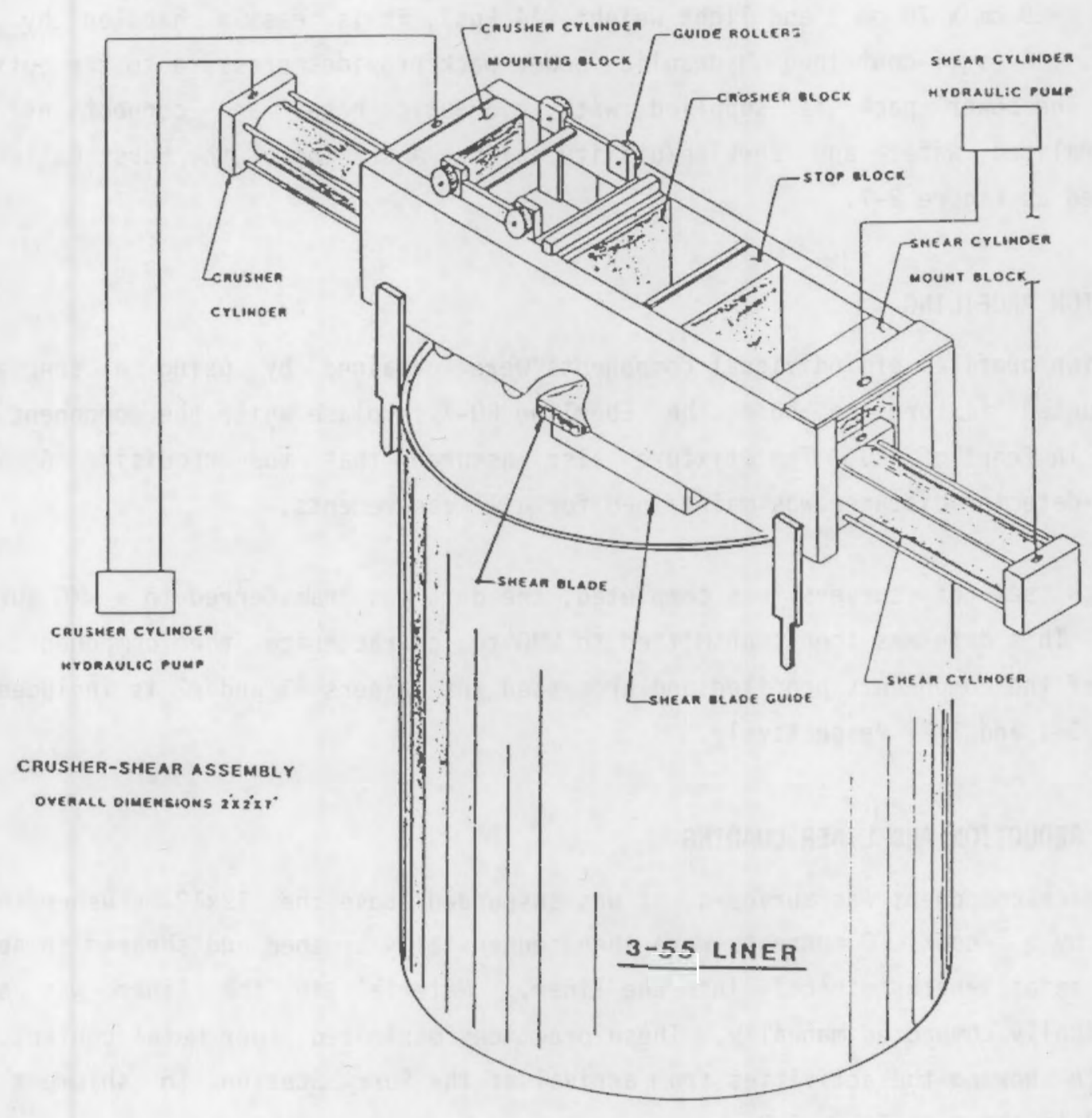

Figure 3-6. Sketch of Crusher/Shear Without Support Stand 
HURST CUTTER

The Hurst Cutter is a hydraulic cutting device utilizing water as the hydraulic medium. The unit consists of two moving cutting blades which develop a cuttina force of $13,600 \mathrm{~kg}(30,000 \mathrm{lbs})$. The cutter can be mounted on extension poles or suspended from a cable for underwater work. This type of cutter has been used in rescue operations under the name of the "Jaws of Life." Due to its compact size $(28 \mathrm{~cm} \times 29 \mathrm{~cm} \times 76 \mathrm{~cm})$ and light weight (14 kgs), it is easily handled by one person. A self-contained hydraulic power pack provides pressure to the cutting head. The power pack is supplied with hydraulic hoses and connections for demineralized water and service/utility air. A drawing of the Hurst Cutter is included as figure 3-7.

\section{RADIATION PROFILING}

Radiation profiles of individual components were obtained by using a specially constructed fixture to hoid the Eberline R0-7 in place while the component was passed in front of it. The fixture also assured that the reouisite 6 inch source-detector distance was maintained for all measurements.

As each set of surveys was completed, the data was transferred to a WMG survey sheet. This data was then transmitted to WMG to characterize the component. A list of the components profiled and processed into Liners $\sharp 1$ and $\# 2$ is included as Tables 3-1 and 3-2, respectively.

\section{VOLUME REDUCTION AND LINER LOADING}

After each component was surveyed, it was suspended above the $12 \times 12$ crusher/shear inlet by a $\mathrm{J}$ hook. Comporents were then sequentially crushed and sheared in about 8 inch axial lengths directly into the liner. Material in the liner was also periodically compacted manually. These practices maximized liner metal content. A schedule showing the activities from arrival at the Surry Station to shipment of cask \#2. is shown in Table $3-3$.

\section{DISPOSAL CONTAINER RADIATION SURVEY}

After packaging, each disposal container was surveyed underwater using an R0-7 meter at contact, one foot and one meter at four radial and three axial locations. One of the liner surveys is shown in Figure 3-8. To prepare shipping 


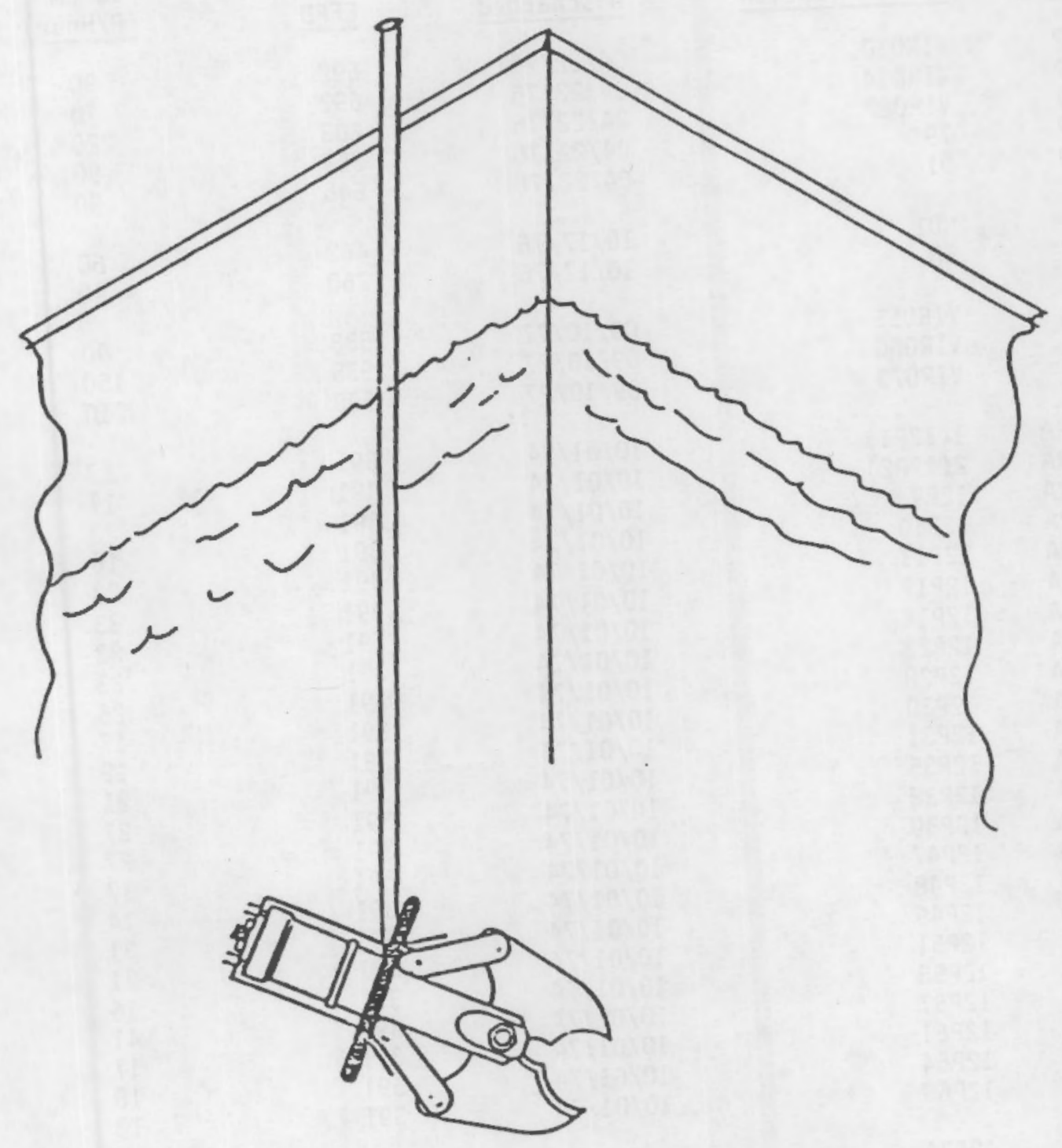

Figure 3-7. Sketch of Hurst Cutter 
Table 3-1

CONTENTS OF LINER \#1

\begin{tabular}{|c|c|c|c|c|}
\hline Type & Identification & $\begin{array}{c}\text { Date } \\
\text { Discharged } \\
\end{array}$ & EFPD & $\begin{array}{l}15 \mathrm{~cm} \\
(\mathrm{R} / \text { Hour }) \\
\end{array}$ \\
\hline$T P$ & VIR010 & $C 4 / 22 / 76$ & 692 & 90 \\
\hline TP & VIR014 & $04 / 22 / 76$ & 692 & 70 \\
\hline$T P$ & VIR082 & $04 / 22 / 76$ & 263 & 220 \\
\hline TP & 79 & $04 / 22 / 76$ & 263 & 90 \\
\hline$T P$ & 91 & $c 4 / 22 / 76$ & 645 & 90 \\
\hline$T P$ & ND1 & $10 / 17 / 76$ & 462 & 60 \\
\hline$T P$ & 88 & $10 / 17 / 76$ & 260 & 40 \\
\hline$T P$ & VIR055 & $09 / 10 / 77$ & 538 & 90 \\
\hline$T P$ & VIR060 & $09 / 10 / 77$ & 538 & 150 \\
\hline TP & VIR073 & $09 / 10 / 77$ & 538 & 210 \\
\hline BPRA & $1(12 P 1)$ & $10 / 01 / 74$ & 391 & 17 \\
\hline BPRA & $2(12 P 2)$ & $10 / 01 / 74$ & 391 & 17 \\
\hline BPRA & $12 \mathrm{Pg}$ & $10 / 01 / 74$ & 391 & 23 \\
\hline BPRA & $12 \mathrm{P} 10$ & $10 / 01 / 74$ & 391 & 16 \\
\hline BPRA & $12 P 11$ & $10 / 01 / 74$ & 391 & 23 \\
\hline BPPA & $12 \mathrm{P} 12$ & $10 / 01 / 74$ & 391 & 33 \\
\hline RPPA & $12 \mathrm{P} 14$ & $10 / 01 / 74$ & 391 & 23 \\
\hline BPRA & $12 P 23$ & $10 / 01 / 74$ & 391 & 23 \\
\hline BPRA & $12 \mathrm{P} 28$ & $10 / 01 / 74$ & 391 & 26 \\
\hline BPRA & $12 \mathrm{P} 30$ & $10 / 01 / 74$ & 391 & 17 \\
\hline BPRA & $12 \mathrm{P} 31$ & $10 / 01 / 74$ & 391 & 19 \\
\hline BPRA & $12 \mathrm{P} 35$ & $10 / 01 / 74$ & 391 & 21 \\
\hline BPRA & $12 \mathrm{P} 38$ & $10 / 01 / 74$ & 391 & 27 \\
\hline BPRA & $12 P 39$ & $10 / 01 / 74$ & 391 & 27 \\
\hline BPRA & $12 P 47$ & $10 / 01 / 74$ & 391 & 17 \\
\hline BPRA & $12 P 48$ & $10 / 01 / 74$ & 391 & 14 \\
\hline RPPA & $12 P 49$ & $10 / 01 / 74$ & 391 & 31 \\
\hline BPRA & $12 \mathrm{P} 51$ & $10 / 01 / 74$ & 391 & 21 \\
\hline BPRA & $12 P 53$ & $10 / 01 / 74$ & 391 & 16 \\
\hline BPRA & $12 \mathrm{P} 57$ & $10 / 01 / 74$ & 391 & 41 \\
\hline BPRA & $12 P 61$ & $10 / 01 / 74$ & 391 & 17 \\
\hline BPRA & $12 P 64$ & $10 / 01 / 74$ & 391 & 16 \\
\hline BPRA & $12 P 66$ & $10 / 01 / 74$ & 391 & 10 \\
\hline BPRA & $12 P 74$ & $04 / 01 / 75$ & 429 & 53 \\
\hline BPRA & $12 P 110$ & $04 / 01 / 75$ & 429 & 41 \\
\hline BPRA & $12 P 112$ & $04 / 01 / 75$ & 429 & 44 \\
\hline BPRA & $12 \mathrm{P} 116$ & $04 / 01 / 75$ & 429 & 49 \\
\hline BPRA & $12 \mathrm{P} 123$ & $04 / 01 / 75$ & 429 & 16 \\
\hline
\end{tabular}


Table 3-1

CONTENTS OF LINER \#1 - CONTINUED

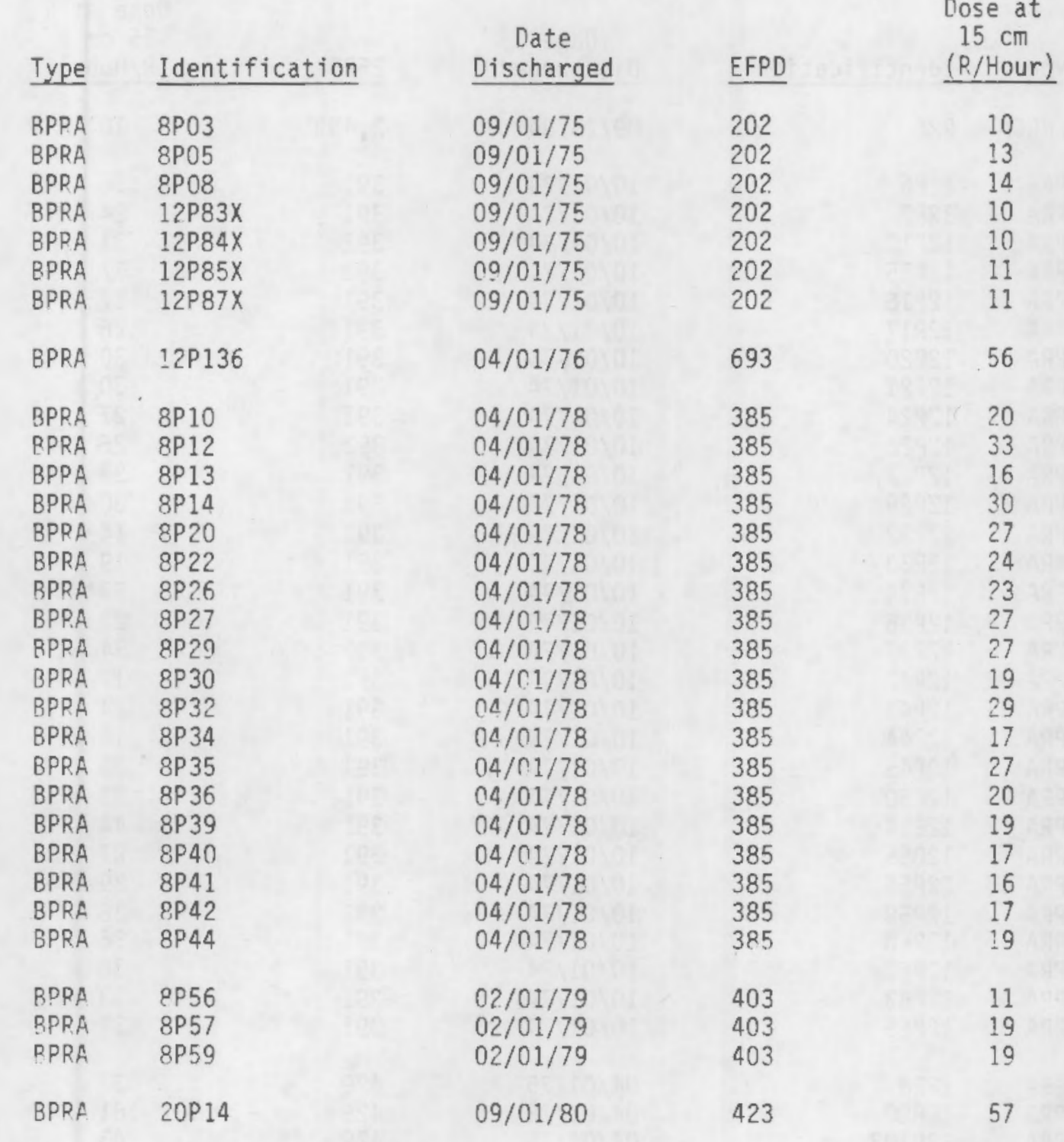


Table 3-2

CONTENTS OF LINER \#2

\begin{tabular}{|c|c|c|c|c|}
\hline Type & Identification & $\begin{array}{c}\text { Date } \\
\text { Discharged } \\
\end{array}$ & EFPD & $\begin{array}{c}15 \mathrm{~cm} \\
\text { (R/Hour) } \\
\end{array}$ \\
\hline PLRCCA & R26 & $09 / 26 / 84$ & 2,499 & 10 \\
\hline BPRA & $12 \mathrm{P} 6$ & $10 / 01 / 74$ & 391 & 36 \\
\hline BPRA & $12 \mathrm{P} 7$ & $10 / 01 / 74$ & 391 & 24 \\
\hline BPRA & $12 \mathrm{P} 13$ & $10 / 01 / 74$ & 391 & 31 \\
\hline BPRA & $12 P 15$ & $10 / 01 / 74$ & 391 & 37 \\
\hline BPRA & 12 P16 & $10 / 01 / 74$ & 391 & 27 \\
\hline BPRA & $12 P 17$ & $10 / 01 / 74$ & 391 & 26 \\
\hline BPRA & $12 \mathrm{P} 20$ & $10 / 01 / 74$ & 391 & 30 \\
\hline BPRA & $12 \mathrm{P} 21$ & $10 / 01 / 74$ & 391 & 30 \\
\hline BPRA & $12 \mathrm{P} 24$ & $10 / 01 / 74$ & 391 & 27 \\
\hline BPRA & $12 P 26$ & $10 / 01 / 74$ & 391 & 26 \\
\hline BPRA & $12 \mathrm{P} 27$ & $10 / 01 / 74$ & 391 & 33 \\
\hline BPRA & $12 P 29$ & $10 / 01 / 74$ & 391 & 30 \\
\hline BPRA & $12 \mathrm{P} 32$ & $10 / 01 / 74$ & 391 & 14 \\
\hline BPRA & $12 \mathrm{P} 33$ & $10 / 01 / 74$ & 391 & 19 \\
\hline BPRA & $? 2 P 34$ & $10 / 01 / 74$ & 391 & 33 \\
\hline BPRA & 12 P 36 & $10 / 01 / 74$ & 391 & 23 \\
\hline BPRA & 12 P 37 & $10 / 01 / 74$ & 391 & 34 \\
\hline BPRA & $12 P 42$ & $10 / 01 / 74$ & 391 & 17 \\
\hline BPRA & $12 P 43$ & $10 / 01 / 74$ & 391 & 24 \\
\hline BPRA & $12 P 44$ & $10 / 01 / 74$ & 391 & 14 \\
\hline BPRA & $12 P 45$ & $10 / 01 / 74$ & 391 & 33 \\
\hline BPRA & $12 P 50$ & $10 / 01 / 74$ & 391 & 33 \\
\hline BPRA & $12 \mathrm{P} 54$ & $10 / 01 / 74$ & 391 & 44 \\
\hline BPRA & $12 \mathrm{P} 55$ & $10 / 01 / 74$ & 391 & 27 \\
\hline BPRA & $12 \mathrm{P} 56$ & $10 / 01 / 74$ & 391 & 39 \\
\hline BPRA & 12.P58 & $10 / 01 / 74$ & 391 & 36 \\
\hline RPRA & $12 P 60$ & $10 / 01 / 74$ & 391 & 36 \\
\hline BPRA & 12 P62 & $10 / 01 / 74$ & 391 & 30 \\
\hline BPRA & $12 P 63$ & $10 / 01 / 74$ & 391 & 33 \\
\hline BPPA & $12 P 65$ & $10 / 01 / 74$ & 391 & 39 \\
\hline BPRA & $12 \mathrm{P} 8$ & $04 / 01 / 75$ & 429 & 33 \\
\hline RPRA & $12 P 80$ & $n 4 / 01 / 75$ & 429 & 61 \\
\hline BPRA & $12 P 103$ & $04 / 01 / 75$ & 429 & 43 \\
\hline BPRA & $12 \mathrm{P} 104$ & $04 / 01 / 75$ & 429 & 43 \\
\hline BPRA & $12 \mathrm{P} 121$ & $04 / 01 / 75$ & 429 & 59 \\
\hline BPRA & $12 P 125$ & $04 / 01 / 75$ & 429 & 44 \\
\hline BPRA & $12 P 128$ & $04 / 01 / 75$ & 429 & 46 \\
\hline BPRA & $12 \mathrm{P} 130$ & $04 / 01 / 75$ & 429 & 40 \\
\hline
\end{tabular}


Table 3-2

CONTENTS OF LINER \#2 - CONTINUED

\begin{tabular}{|c|c|}
\hline Type & Identification \\
\hline $\begin{array}{l}\text { BPRA } \\
\text { BPRA } \\
\text { BPRA } \\
\text { BPRA } \\
\text { BPRA } \\
\text { BPRA }\end{array}$ & $\begin{array}{l}8 P 01 \\
8 P 02 \\
12 P 81 X \\
12 P 82 X \\
12 P 86 X \\
12 P 88 X\end{array}$ \\
\hline $\begin{array}{l}\text { BPRA } \\
\text { BPRA } \\
\text { BPRA } \\
\text { BPRA } \\
\text { RPRA } \\
\text { BPRA } \\
\text { BPPA } \\
\text { BPRA } \\
\text { BPRA } \\
\text { BPRA }\end{array}$ & $\begin{array}{l}8 P 15 \\
8 P 16 \\
8 P 18 \\
8 P 19 \\
8 P 21 \\
8 P 25 \\
8 P 28 \\
8 P 31 \\
8 P 37 \\
8 P 38\end{array}$ \\
\hline $\begin{array}{l}\text { BPRA } \\
\text { EPRA }\end{array}$ & $\begin{array}{l}8 P 52 \\
8 P 53\end{array}$ \\
\hline
\end{tabular}

\begin{tabular}{lll}
$\begin{array}{c}\text { Date } \\
\text { Discharged }\end{array}$ & & \\
\cline { 1 - 1 } 09 EFPD \\
$091 / 01 / 75$ & & 202 \\
$09 / 01 / 75$ & & 202 \\
$09 / 01 / 75$ & & 202 \\
$09 / 01 / 75$ & & 202 \\
$09 / 01 / 75$ & & 202 \\
$09 / 01 / 75$ & & 202 \\
$04 / 01 / 78$ & & 385 \\
$04 / 01 / 78$ & & 385 \\
$04 / 01 / 78$ & 385 \\
$04 / 01 / 78$ & 385 \\
$04 / 01 / 78$ & 385 \\
$04 / 01 / 78$ & 385 \\
$04 / 01 / 78$ & 385 \\
$04 / 01 / 78$ & 385 \\
$04 / 01 / 78$ & 385 \\
$04 / 01 / 78$ & 385 \\
$02 / 01 / 79$ & \\
$02 / 01 / 79$ & 403 \\
& & 403
\end{tabular}

Dose at.

$15 \mathrm{~cm}$

(R/Hour)

21

10

10

20

20

20

31

41

57

11

19

19

31

23

23

21

26

29 
Table 3-3

SCHEDULE OF ACTIVITIES

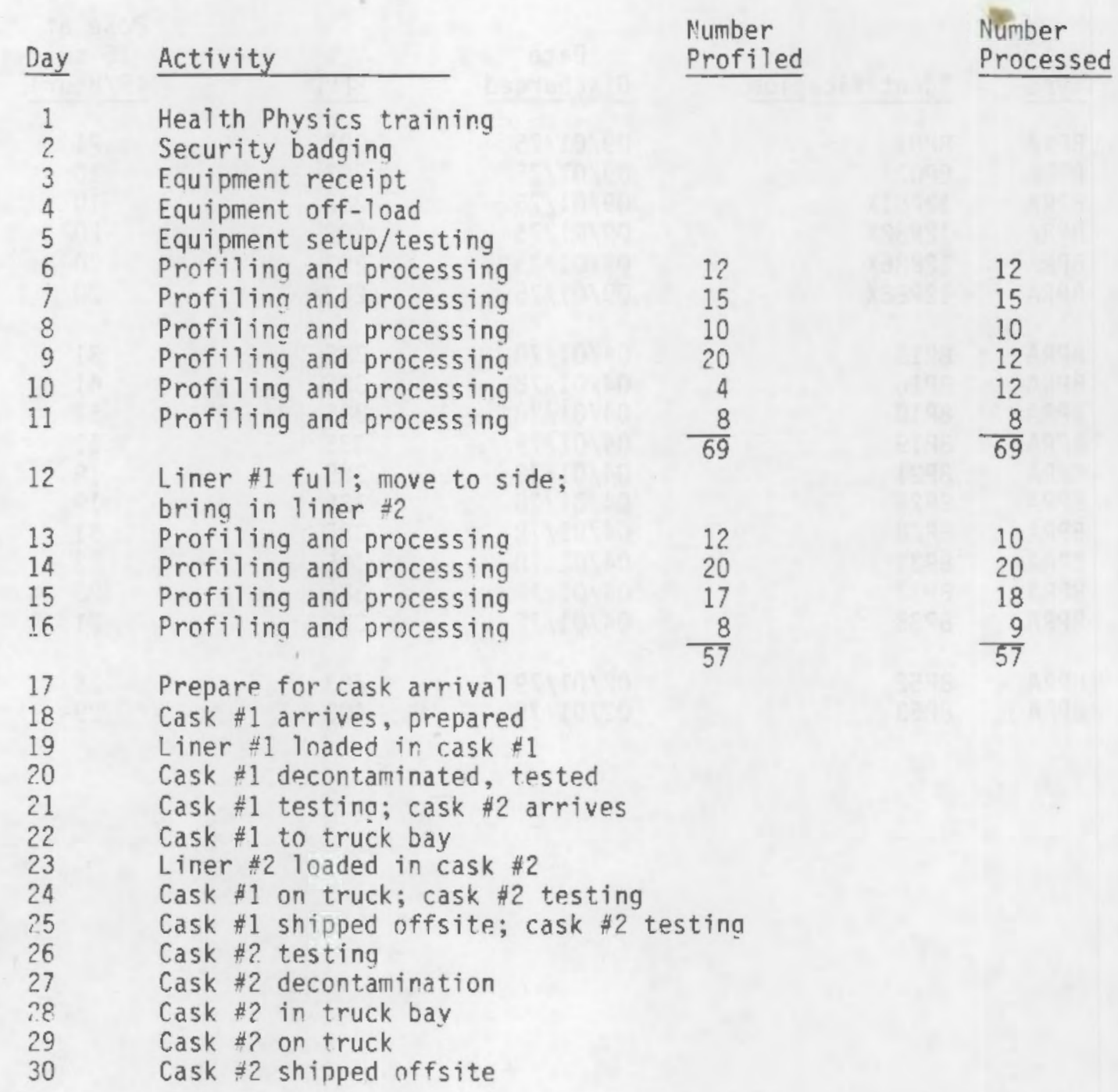




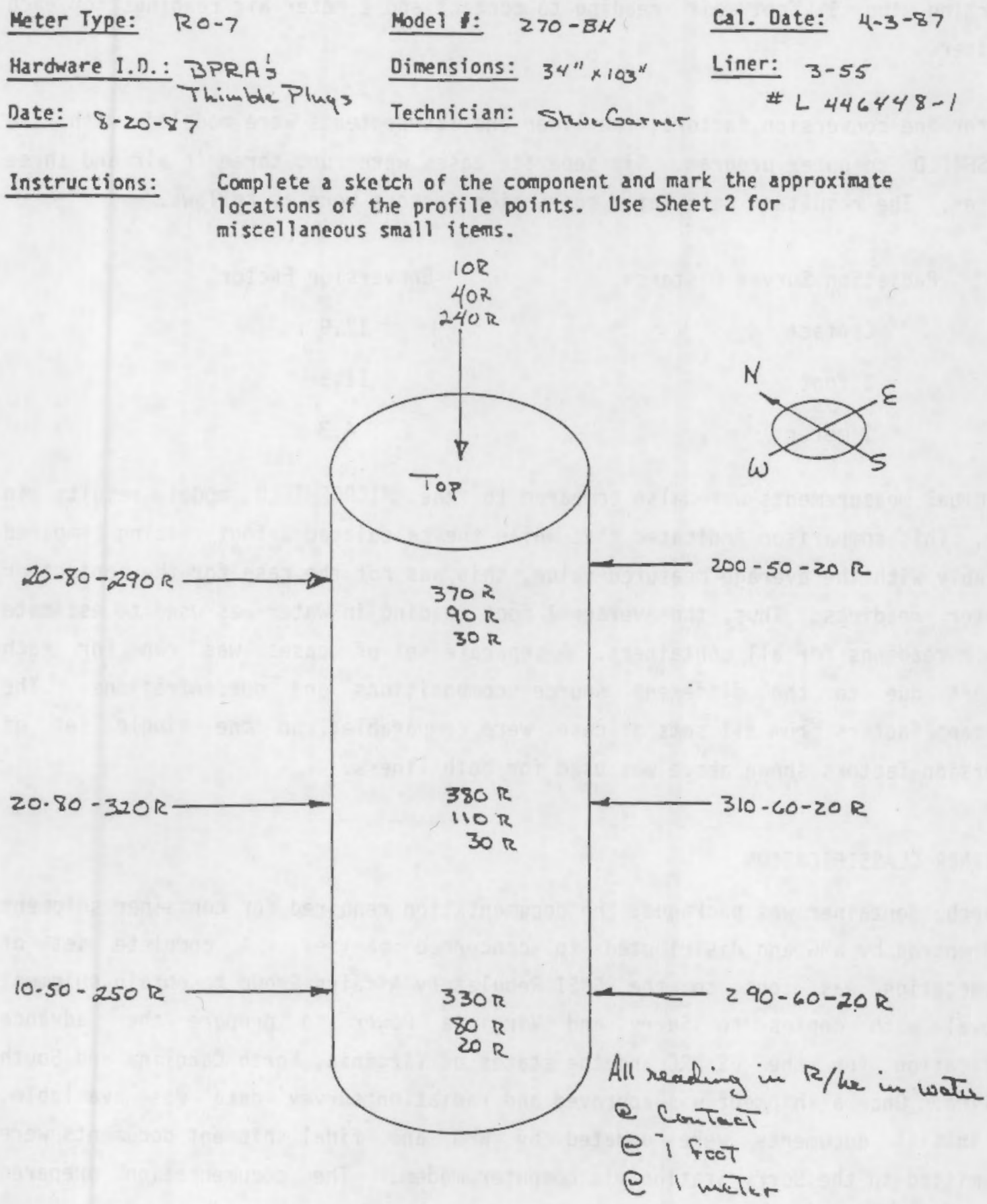

Figure 3-8. Liner \#1 Dose Profile 
documentation, these underwater readings were converted to dose rate readings in air by multiplying the 1 font underwater reading by a factor of 11.3 and then converting the 1 font air reading to contact and 1 meter air readings for each container.

To determine conversion factors, the liner and its contents were modeled with the MICROSHIELD computer program. Six separate cases were run; three in air and three in water. The resultant calculated conversion factors were as follows.

$$
\begin{array}{cc}
\text { Radiation Survey Distance } & \text { Conversion Factor } \\
\text { Contact } & 17.9 \\
1 \text { foot } & 11.3 \\
1 \text { meter } & 4.3
\end{array}
$$

The actual measurements were also compared to the MICROSHIELD model results in water. This comparison indicated that while the calculated 1 foot reading compared favorably with the average measured value, this was not the case for the contact or 1 meter readings. Thus, the average 1 foot reading in water was used to estimate ail air readings for all containers. A separate set of cases was run for each shipment due to the different source compositions and concentrations. The resultant factors from all sets of cases were comparable, so the single set of conversion factors shown above was used for both liners.

\section{CONTAINER CLASSIFICATION}

As each container was packaged, the documentation required for container shipment was prepared by WMG and distributed to concerned parties. A complete set of documentation was sent to the CNSI Regulatory Affairs Group to obtain shipment approval with copies to Surry and Virginia Power to prepare the advance notification for the US NRC and the states of Virqinia, North Carolina and South Carolina. Once a shipment was approved and radiation survey data was available, the initial documents were updated by WMG and final shipment documents were transmitted to the Surry Station via computer modem. The documentation prepared for each shipment included:

- An itemized inventory of 1 iner content. 
- A classification status report ngenerated during liner packaging. Figure 3-9 shows this report for liner $\# 1$.

- Preliminary shipment documentation used to obtain prior approval from CNSI for the shipment and to prepare NRC/state advance notification paperwork. This includes the RSR without liner radiation levels, shipment numbers, dates and signatures, and the Class C shipment documentation required by Barnwell.

- Final shipment documentation, which is prepared after shipment approval. This includes the RSR with liner radiation levels, and shipment date, the Barnwell Class $\mathrm{C}$ documentation and a shipment decay heat report. 


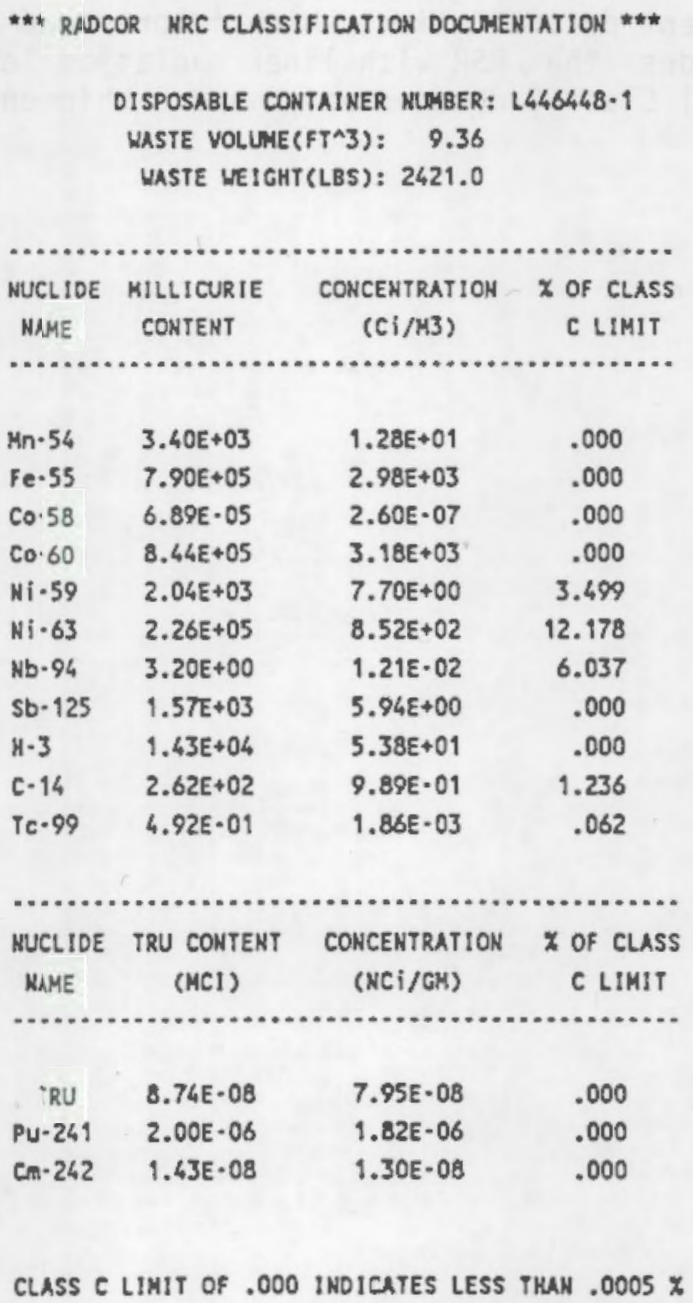

Figure 3-9. Liner \#1 Classification Documentation 


\section{Section 4}

TRANSPORT AND DISPOSAL

The CNS 3-55 cask is a steel-encased, lead-shielded cask with crushable impact limiters. The cask is a steel cylinder $3.4 \mathrm{~m}$ (133.75 in) long by $1.3 \mathrm{~m}$ (50.5 in) in diameter with cavity dimensions of $0.9 \mathrm{~m}$ (36 in) in diameter by $2.8 \mathrm{~m}$ (111 in) long. Shielding is provided by $15 \mathrm{~cm}$ (6 in) of lead in the sides and closure base plate and $13 \mathrm{~cm}(5.25 \mathrm{in})$ in the closed end.

The outside steel encasement is made up of two, $1.3 \mathrm{~cm}$ plates on the sides and three plates totaling $6.7 \mathrm{~cm}$ on the end. The containment vessel is a $0.64 \mathrm{~cm}$ thick cylinder with a $1.25 \mathrm{~cm}$ end plate. The shells are welded together with the lead shielding poured to fill the annular and end spaces.

The removable, flanged and recessed base plate weldment consists of $1 \mathrm{~cm}$ and $3.2 \mathrm{~cm}$ outside plates and a $1.6 \mathrm{~cm}$ inside plate. The space between the plates is lead-filled. The base plate is secured to the cask body by twelve, $3.8 \mathrm{~cm}$ high strength bolts and nuts and is sealed with two silicone 0-rings.

The cavity is penetrated by a vent line at the closed end and a drain line through the base plate. The vent line is sealed by a gasketed and shielded plug. The drain line is sealed with a 1.7 bar relief valve.

Cask appendages include two, $20 \mathrm{~cm}$ lifting trunnions and two, $10 \mathrm{~cm}$ removable tilting trunnions on the side of the cask.

Pemovable impact limiters are provided at the cask ends and at the two, $20 \mathrm{~cm}$ trunnions. The former consists of a series of $15 \mathrm{~cm}$ diameter closed end tubes. Each impact limiter has tubes approximately $15 \mathrm{~cm}$ long around the end periphery. The closure end impact limiter has twelve tubes, six that are about $15 \mathrm{~cm}$ long and six that are about $5 \mathrm{~cm}$ long, around the sides. 
The cask is secured horizontally to a skid that is mounted to the transport vehicle for shipment. A sunshade or metal personnel barrier is provided.

The weight of the CNS 3-55, excluding the skid and sunshade is approximately 27,500 kas. The skid weighs about $1900 \mathrm{kgs}$. The trailer weighs about $5900 \mathrm{kgs}$ and has a capacity of $32,000 \mathrm{kgs}$.

Table 4-1 provides a summary of the contents of the two shipments made using the CNS 3-55 liners and casks. Gamma radiation dose rates at the exterior surface of the two casks ranged from $60 \mathrm{mrem} /$ hour to $80 \mathrm{mrem} / \mathrm{hr}$. The maximum dose rate at one meter from the metal personnel barrier was $7 \mathrm{mrem} / \mathrm{hr}$. A series of photographs is included as Figures $4-1$ through $4-7$ showing some of the handling operations of a loaded CNS 3-55 cask. 
Table 4-1

SHIPMENT SUMMARY

$\begin{array}{lrr}\text { Shipment Date } & 09 / 03 / 87 & 09 / 08 / 87 \\ \text { Liner ID No. } & \text { L446448-1 } & \text { L446448-2 } \\ & & \\ \text { Contents: } & 59 & 06 \\ \text { BPRA's } & 10 & 1 \\ \text { Thimble Plugs } & 0 & \\ \text { PLRCCA's } & & 9.67 \\ & 9.36 & \\ \text { Metal Volume }\left(\mathrm{ft}^{3}\right) & & 2,150 \\ & 1,890 & 3 \\ \text { Total Curies } & & 0 \\ & & \\ \text { Major Nuclides (Curies) } & 3 & 1,010 \\ \text { Mn-54 } & 790 & 283 \\ \text { Fe-55 } & 0 & 20 \\ \text { Co-58 } & 844 & 14.7 \\ \text { Co-60 } & 226 & \end{array}$




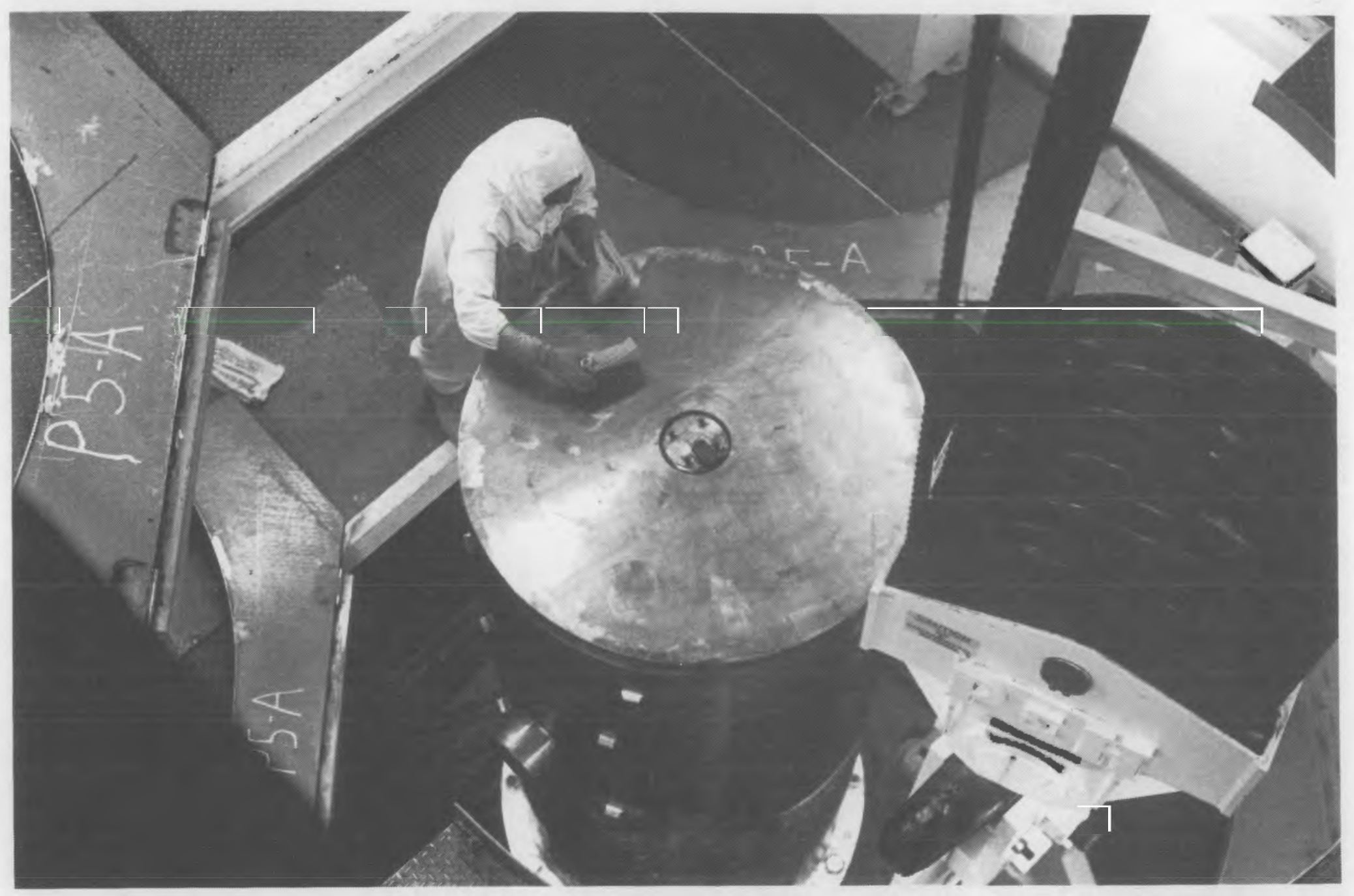

Figure 4-1. Loaded Cask in Decontamination Bay After Completion of Testing 


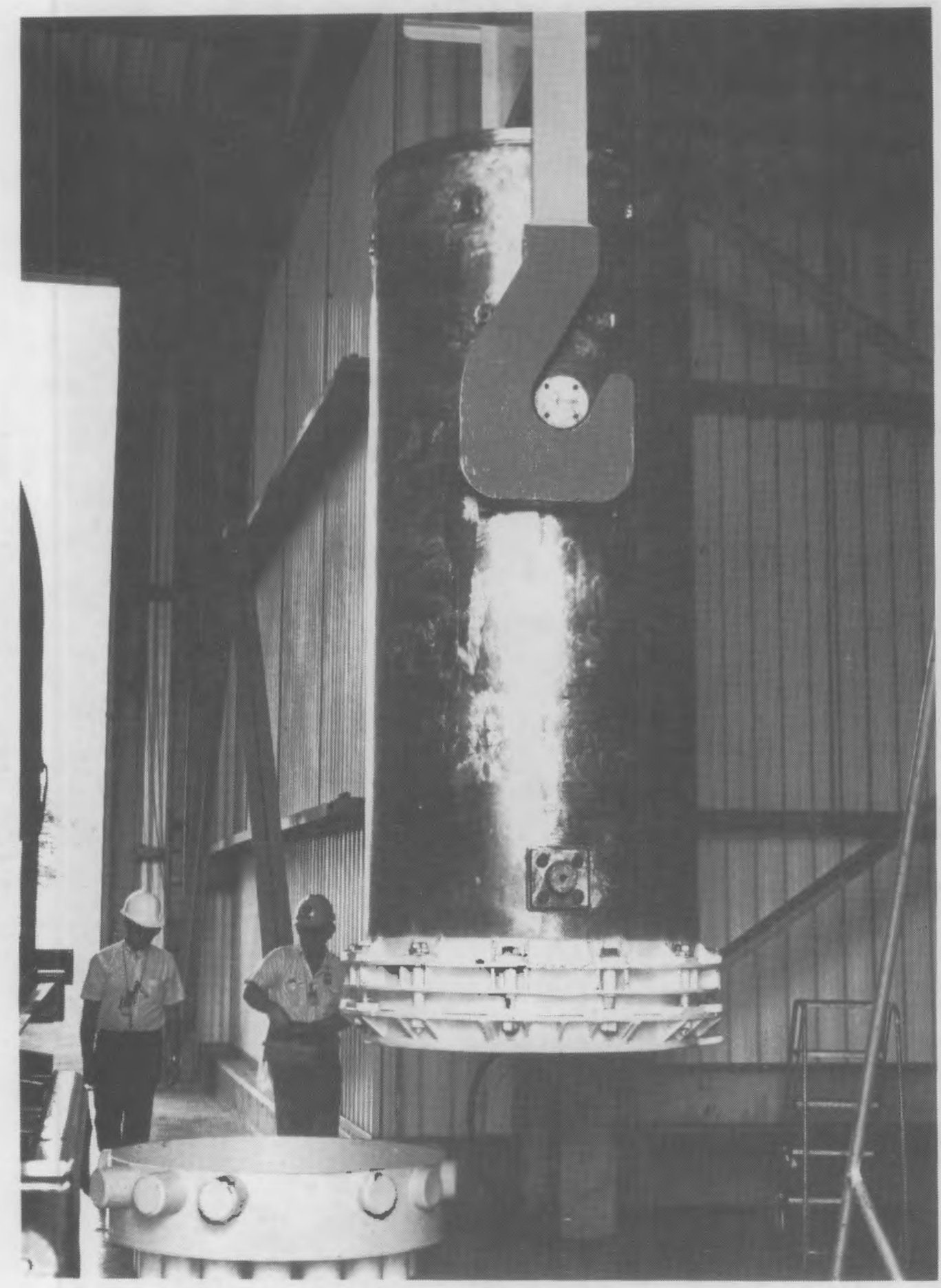

Figure 4-2. Loaded Cask Being Lifted in Truck Bay 


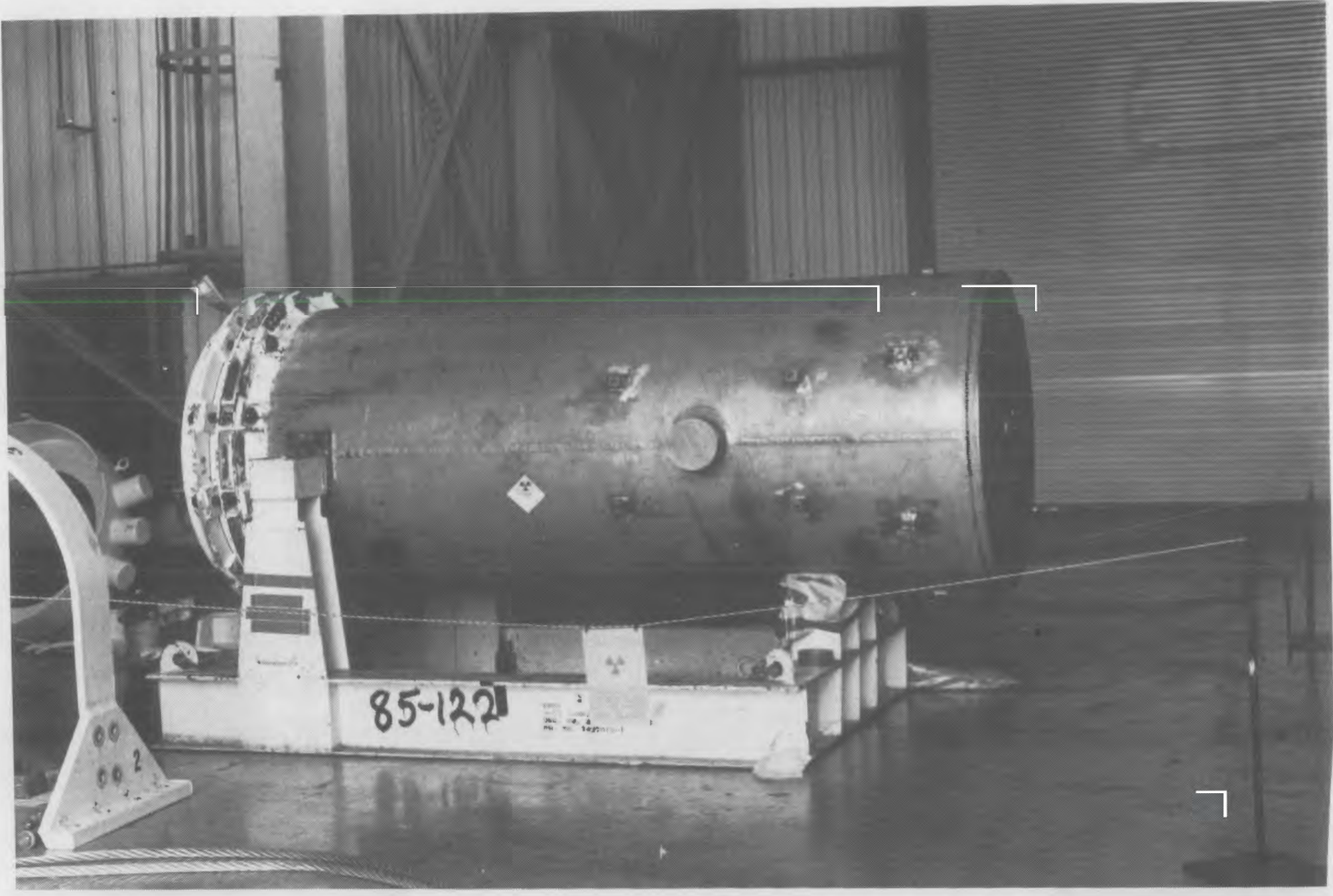

Figure 4-3. Loaded Cask on Tilting Skid 


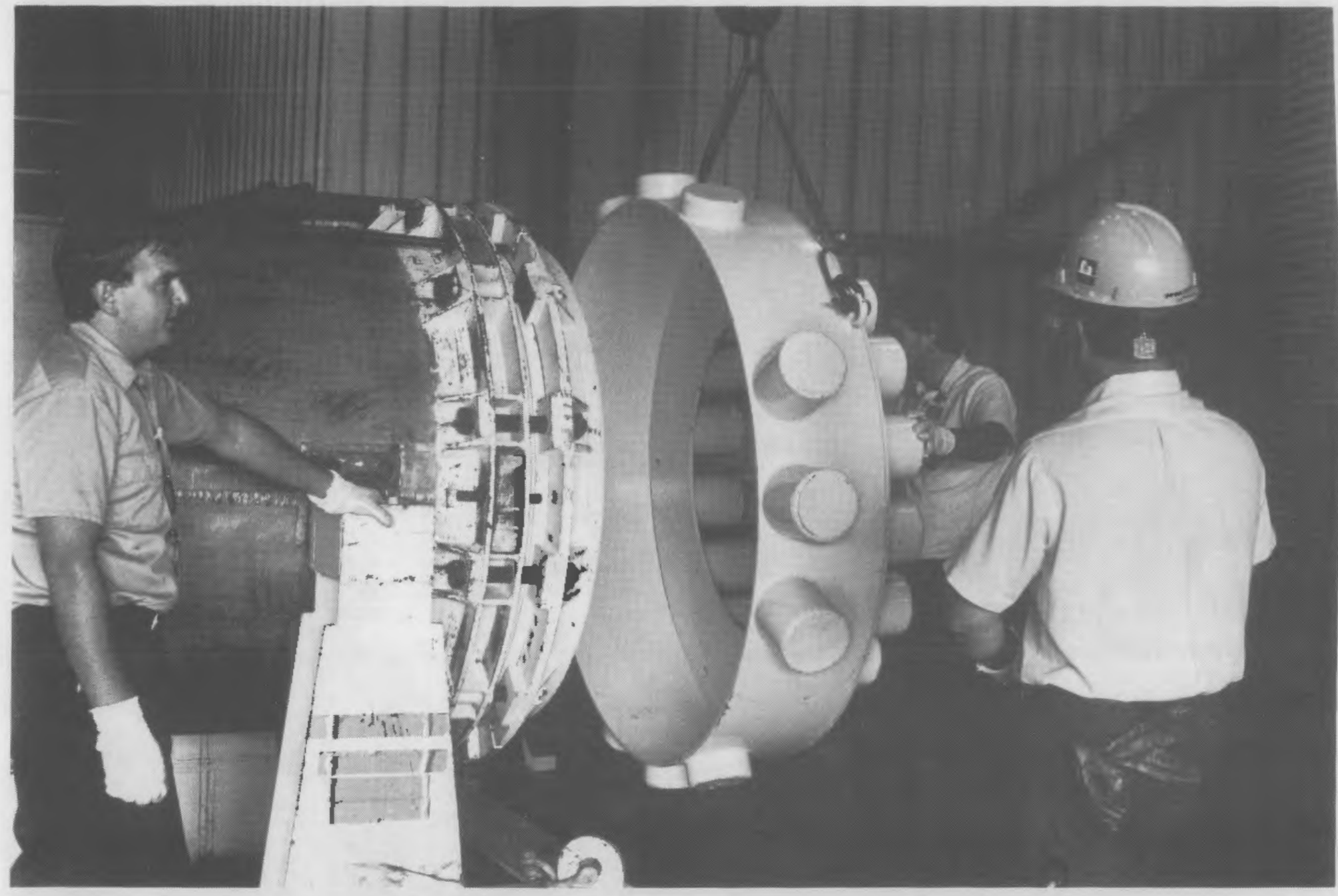

Figure 4-4. Installing Bottom Impact Limiter 


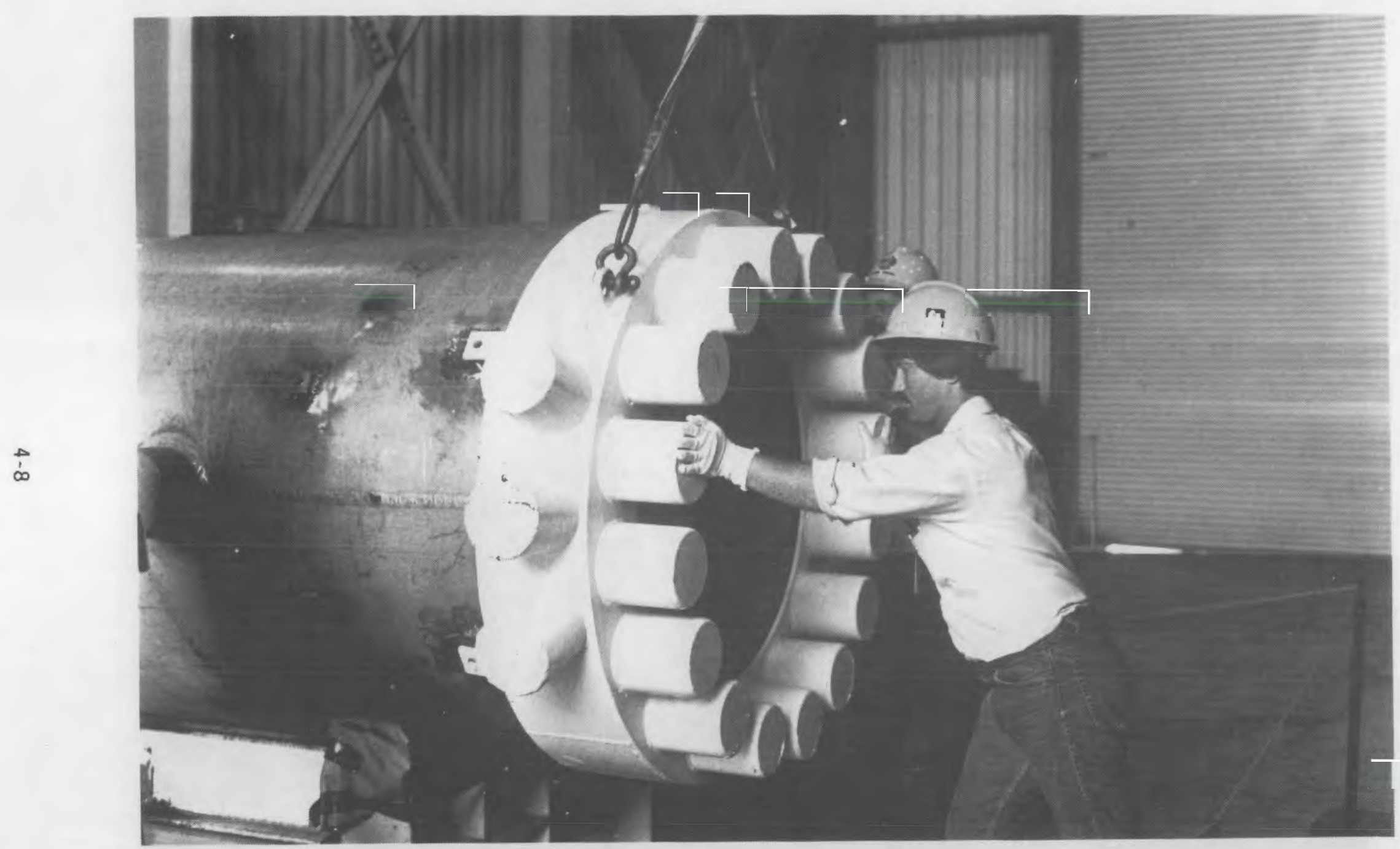

Figure 4-5. Installing Top Impact Limiter 


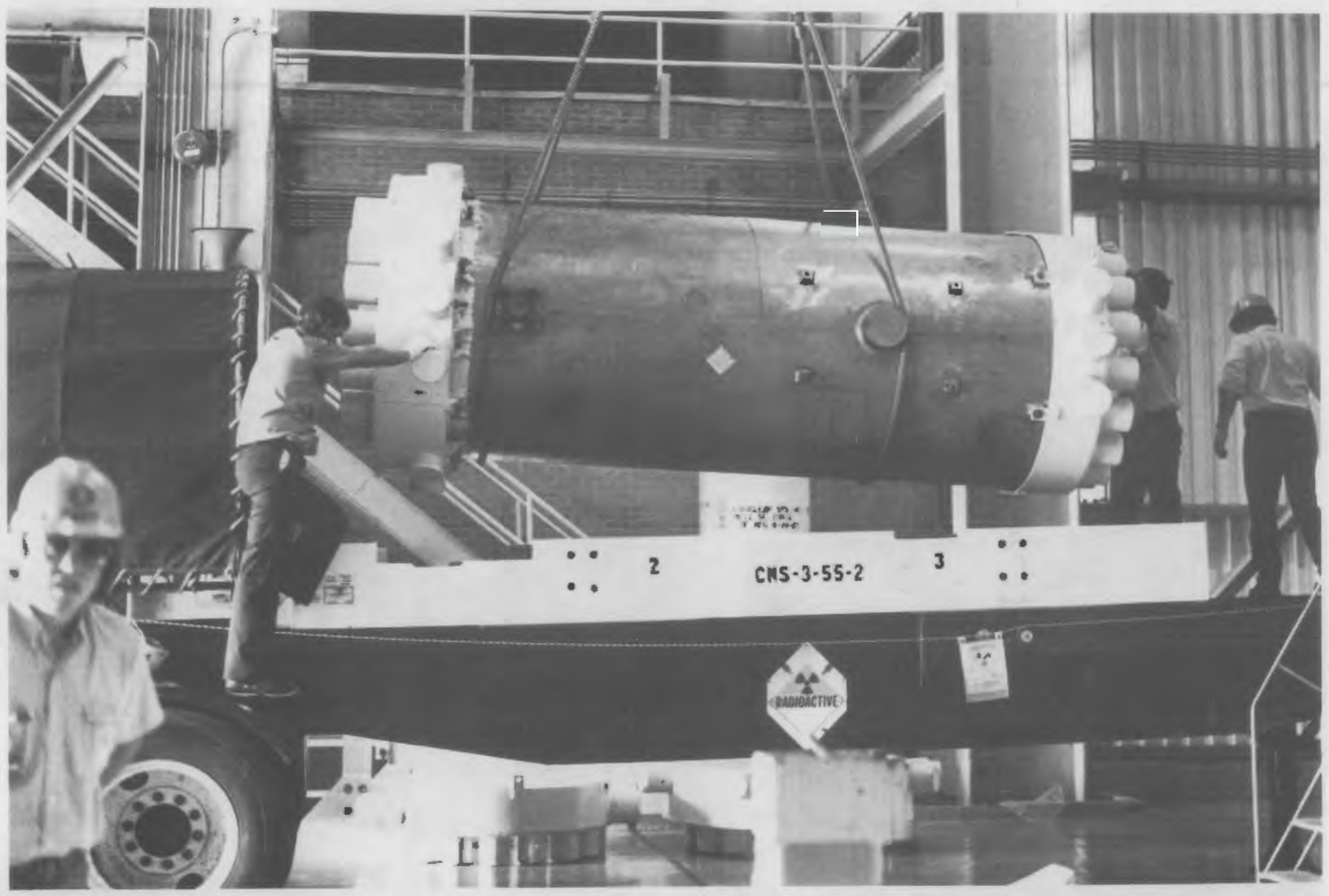

Figure 4-6. Lifting Cask Onto Trailer 


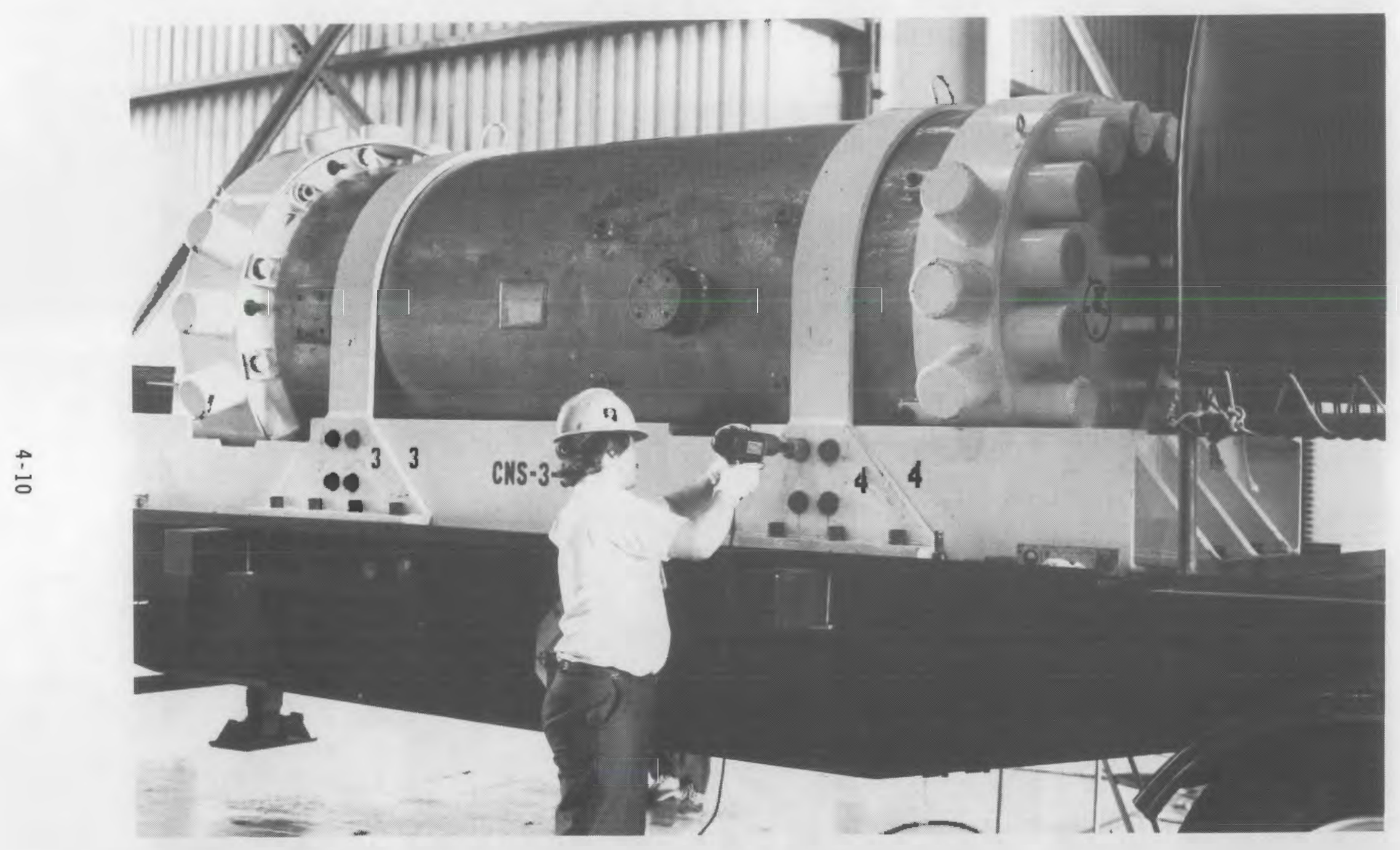

Figure 4-7. Installing Cask Tie-down 
- Section 5

COSTS

Table 5-1 provides an estimate for each type of cost. The cost to process the components was approximately $\$ 182,426$ or $47 \%$ of the total cost and it represents $\$ 1,341$ per component. The remaining $\$ 209,074$ for the two 1 iners, cask rental and transport and liner disposal bring the total cost to $\$ 391,500$ or $\$ 2,879$ per component. This unit cost represents $0.0175 \mathrm{Mi} 11 \mathrm{~s} / \mathrm{KwHr}$, based on the use of 52 BPRAs in one 16.5 month operating cycle of either 800 megawatt Surry reactor. This unit cost also compares very favorably with the $\$ 50,000$ marginal cost for a storage location in the spent fuel storage pool. This marginal cost represents that cost to place a spent fuel assembly (and component) in dry storage in order to provide a location in the storage pool just for the storage of an excess insert component. 
Table 5-1

COST BREAKDOWN

\begin{tabular}{lr}
\multicolumn{1}{c}{ Cost Type } & Cost \\
\cline { 2 - 2 } Equipment and Personnel & 133,641 \\
CNS 3-55 Liners (2), Cask Rental and Transport & 81,967 \\
Disposa1 of Liners (2) & 127,107 \\
Waste Classification & 10,692 \\
Mobilization of Equipment and Personnel & 8,909 \\
Demobilization of Equipment and Personnel & 8,909 \\
Procedures, Site Visits, and Project Management & 20,275 \\
& TOTAL
\end{tabular}




\section{Section 6}

CONCLUSIONS

The irradiated insert component processing conducted by CNSI in August 1987 using a light-duty crusher/shear and Hurst cutter combination provided a quick (10 days) and low personnel dose solution to the problem of storage of excess amounts of these components. A small amount of glass "snow" from the crushed BPRA rods was present in a small area of the pool near the crusher/shear, but this "snow" was easily removed.

Characterization of the components and classification of the disposal liner for burial as Class $C$ low-level waste was quick and easy and was also relatively inexpensive.

These shipments of irradiated hardware represented the first 3-55 liners which contained irradiated hardware processed with the new CNSI light-duty crusher/shear. The amount of hardware packaged in the liners for this project was a factor of 4 to 5 greater than that packaged in previous 3-55 PWR hardware proiects, and resulted in a reduced disposal volume and lower cost. 



\section{Section 7 \\ REFERENCES}

1. J. M. Creer, et al. The CASTOR V/21 PWR Spent-Fuel Storage Cask: Testing and Analyses. Electric Power Research Institute, November 1986. NP-4887.

2. M. A. McKinnon, et aT. The TN-24P PWR Spent-Fuel Storage Cask: Testing and Analyses. Electric Power Research Institute, ApriT 1987. NP-5128.

3. M. A. Mckinnon, et al. The MC-10 PWR Spent-Fuel Storage Cask: Testing and Analyses. Electric Power Research Institute, July 1987. NP-5268.

4. M. A. McKinnon, et. al. Testing and Analyses of the TN-24P PWR Spent-Fuel Dry Storage Cask Loaded with Consolidated Fuel. Electric Power Research Institute, February 1989. NP-6191.

5. H. S. McKay, et. al. An Independent Spent-Fuel Storage Installation at Surry Station: Design and Operation. Electric Power Research Institute, July 1989. NP-6032.

6. PADCOR - A Computer Code to Characterize, Classify and Document Packaged Irradiated Hardware. WMG, Inc., October 1985. WMG-8502, Revision 1.

7. MICROSHIELD User's Manual, Version 2.0. Grove Engineering, 1985. 
